\title{
Questão fundiária e sucessão da terra na fronteira Oeste da Amazônia
}

José Heder Benatti - Doutor em Ciência e Desenvolvimento Socioambiental, pesquisador do CNPq e professor da Universidade Federal do Pará.

Edna Maria Ramos de Castro - Doutora em Ciências Sociais pela Ecole des Hautes Etudes en Sciences Sociales-França e professora/pesquisadora da UFPA..

Thomas Peter Hurtienne - Doutor em Economia pela Freie Universitat Berlin-Alemanha. E professor da Universidade Federal do Pará.

Roberto Araújo de Oliveira Santos - Historiador. Doutor em Ethnologie pela Université de Paris X, Nanterre e pesquisador do Museu Paraense Emílio Goeldi.

Roselene de Souza Portela - Doutoranda do Programa de Pós-Graduação em Desenvolvimento Sustentável do Trópico Úmido do NAEA/UFPA.

\section{Resumo}

Foram criados na segunda metade do século XX, no Brasil, diversos órgãos fundiários estaduais que buscavam solucionar os crescentes conflitos de terra. Um dos principais objetivos dos órgãos fundiários era garantir o acesso à propriedade rural, ou seja, possibilitar que o maior número de pessoas pudesse ter um pedaço de terra para trabalhar. Outro papel era o de gestão do patrimônio público. Contudo, na prática verificou-se que a gestão se resumia mais em incorporar as terras devolutas ao seu patrimônio e depois transferi-lo para os entes privados, do que em pensar em uma política na qual seria definida, pelos institutos de terra, também a forma de uso e manejo dos recursos naturais. Procuramos mostrar essa questão relacionada à produção de diversas formas de conflitos fundiários relacionados à atuação dos órgãos fundiários. Mas também a compreensão destes em uma nova conjuntura política e jurídica, pois é preciso definir, dentro da estrutura organizacional governamental, qual é o órgão ou a instância responsável pela execução da política agrária, pela gestão dos recursos naturais renováveis e, principalmente, pelas terras devolutas. A análise sobre a situação fundiária e dos conflitos na área da Br-163 (Rodovia CuiabáSantarém), é elucidativa de como a visualização da estrutura fundiária é importante para a elaboração de um plano estratégico de ordenamento social, econômico e ecológico.

\section{Palavras-Chave}

Amazônia, questão fundiária, Estado, ordenamento territorial, conflitos socioambientais, rodovia Cuiabá-Santarém.

\section{Abstract}

In Brazil, in the second half of the 20th century, several state land organizations were created, which tried to solve the growing conflicts for lands. One of the main objectives of these state land organizations was to garantee the access to the rural property, that is, to make that the largest number of people could have a piece of land to work. Another role was that of the management of the public patrimony. However, in practice, one noticed that the management summed up more in incorporating the devoluted lands into the patrimony and then transferring them to private people, than in thinking about a policy in which the way of use and management of the natural resources would be defined by the institutes of lands. We tried to show this issue related to the production of several forms of land conflicts linked to the performance of the state land organizations, as well as the understanding of these conflicts in a new legal and political conjuncture, since it is necessary to define, in the governmental organizational structure, which one is the state organization or the instance responsible for the execution of the land policy, for management of the natural renewed resources and, principally, for the devoluted lands. The analysis of the land situation and of the conflicts in the area of Br-163 (Cuiabá-Santarém Road) is highlighted in how the visualization of the land structure is important for the elaboration of a strategic plan of a social, economical and ecological ordering.

\section{Keywords}

Amazônia, land issue, State, territorial organization, socio-environmental conflicts, CuiabáSantarém Road. 
José Heder Benatti / Edna Castro / Thomas Hurtienne / Roberto Araújo de Oliveira Santos / Raimunda Nonata Monteiro da Silva / Roselene de Souza Portela

\section{QUESTÃO FUNDIÁRIA}

Na segunda metade do século XX foram criados, por meio de assentamentos, regularização fundiária e etc., diversos órgãos fundiários estaduais no Brasil que buscavam solucionar os crescentes conflitos de terra. A principal, ou talvez única, exigência desses órgãos públicos era que o "cliente" da reforma agrária tivesse a capacidade de tornar a terra produtiva. Com esse intuito, os recursos naturais foram substituídos pelo capim e por diversas culturas agrícolas para garantir a posse da terra, levando à destruição da floresta. A própria lei e as instruções normativas do Incra determinavam que a produtividade de um imóvel era diretamente proporcional à área de mata derrubada.

Assim, um dos principais objetivos dos órgãos fundiários era garantir o acesso à propriedade rural, ou seja, possibilitar que o maior número de pessoas pudesse ter um pedaço de terra para trabalhar. Para exemplificar o que afirmamos, podemos citar os principais objetivos contidos nos estatutos dos institutos de terras: a) extremar o domínio público do particular; b) regularizar, obter, reduzir, aumentar ou cancelar a posse ou propriedade pública ou privada das terras que sejam, tenham sido ou venham a ser consideradas devolutas; c) organizar o Cadastro Rural do Estado, eliminando ou prevenindo os problemas de localização, superposição e excesso de áreas que sejam ou tenham sido devolutas; d) coordenar todos os problemas fundiários do Estado com os órgãos correlatos, promovendo gestões junto a estes.

Outro papel desempenhado pelos institutos de terra era o de gestão do patrimônio público. Contudo a gestão se resumia mais em incorporar as terras devolutas ao seu patrimônio e depois transferi-lo para os entes privados, do que em pensar em uma política na qual definiria, pelos institutos de terra, também a forma de uso e manejo dos recursos naturais. Corroborando essa idéia, temos como exemplo a finalidade de: a) precisar, retificar, aviventar e demarcar os limites estaduais ou municipais; b) definir as áreas dominicais que, dentro do território do Estado, constituam patrimônio dele ou de quaisquer outras entidades de direito público; c) administrar as terras devolutas do Estado; d) promover, periodicamente, a avaliação das terras devolutas; e) fixar quais as áreas que podem ser alienadas, quer em regime de licitação, quer em regime de requerimento ou outra forma prevista na legislação agrária.

Logo, podemos nos indagar: qual é o atual papel do órgão fundiário? Ou será que esse órgão público está historicamente superado?

A resposta a essa pergunta está relacionada à atuação dos órgãos estatais e à compreensão de seu papel em uma nova conjuntura política e jurídica, pois 
é preciso definir, dentro da estrutura organizacional governamental, qual é o órgão ou a instância que ficará responsável pela execução da política agrária e da gestão dos recursos naturais renováveis do Estado (em particular a terra, o solo e a floresta), principalmente as terras devolutas.

Entendemos como política agrária e gestão dos recursos naturais renováveis as políticas de regularização fundiária, de estruturação da propriedade rural, de manejo dos recursos naturais nos imóveis rurais, pois é necessário interagir as diferentes medidas públicas, a fim de buscar maior eficácia nos resultados. Deste modo, há uma mudança na compreensão do objeto, não somente a propriedade, como mera transferência de terra do patrimônio público para o privado, mas também a gestão racional dos recursos, sejam para fins agrícolas, pecuários, florestais ou extrativistas.

O motivo que nos leva a pensar em um órgão ou instância administrativa, garantida a participação da sociedade civil organizada, que articule política fundiária e gestão dos recursos naturais renováveis parte do pressuposto de que a agricultura não produz apenas bens materiais mas também bens imateriais (a paisagem, a beleza cênica); não só produtos alimentares mas também produtos não alimentares (matéria-prima para indústria, insumos utilizados para produção de energia); não só produções comerciais mas também produções não comerciais (biodiversidade, serviços ambientais). A agricultura tem que fazer convergir o interesse particular (que é a produção de alimentos) e o interesse geral (a proteção ambiental), superando a lógica produtivista que desvinculou a atividade agrícola da sua função de preservação ambiental.

O primeiro passo para compreender o novo papel que o órgão ou instância administrativa poderá desempenhar é ter uma visão geral dos diversos usos do espaço. Neste contexto, a visualização da estrutura fundiária é importante para a elaboração de um plano estratégico de desenvolvimento sustentável, que tem como objetivo principal o ordenamento social, econômico e ecológico, cujas ações serão voltadas para o desenvolvimento do Estado a médio e a longo prazo. Neste contexto, o processo de gestão das terras públicas estaduais, a sua destinação e ocupação precisam ser transparentes e claros para os planejadores governamentais e para a sociedade civil.

Desta forma, podem-se elaborar indicativos de tendências e potenciais visando à nova ordem de assentamento humano, equacionado com a conservação ambiental, com os investimentos econômicos, com a expansão da matriz energética e com a eqüidade de infra-estrutura física e social, para um planejamento melhor a curto, a médio e a longo prazo. 
José Heder Benatti / Edna Castro / Thomas Hurtienne / Roberto Araújo de Oliveira Santos / Raimunda Nonata Monteiro da Silva / Roselene de Souza Portela

Um aspecto que deve ser analisado, quando se pretende definir instrumentos estratégicos para implementar o Zoneamento Ecológico-Econômico (ZEE) em uma determinada região, é a questão da situação fundiária do Estado. Mesmo que num primeiro momento este assunto não pareça prioritário, que não venha interferir diretamente na fase de elaboração do Zoneamento, quando se pensar em implementá-lo, a maneira como as terras estão ordenadas dentro do Estado pode ser determinante para o sucesso do ZEE.

A introdução desta discussão no zoneamento está relacionada, principalmente, à tradição de os Estados amazônicos possuírem uma estrutura agrária desordenada, na qual a distinção sobre o que é patrimônio público e privado e a definição de quais são as terras pertencentes ao patrimônio federal e estadual encontram-se muito desorganizadas, imprecisas.

Portanto, pensar em um órgão fundiário (ou na política pública para a questão fundiária) é necessariamente buscar sinergia com as demais secretarias e órgãos da União e do Estado. Na contemporaneidade, a propriedade rural, além de cumprir o seu papel de produzir alimentos, também desempenha a função pública da gestão ambiental, ou seja, de gerir da melhor forma o espaço dentro do imóvel rural, pois o paradoxo entre produzir ou conservar o meio ambiente só existe para a concepção produtivista, que na prática acaba privilegiando mais o uso tradicional da terra.

O princípio da produtividade, que está relacionado com o desenvolvimento econômico, é compreendido sob um novo patamar, no qual o potencial produtivo será mensurado pelos seus efeitos econômicos e ambientais. É neste contexto que deve atuar o Poder Público. Nesta perspectiva, é importante pensar também a participação da sociedade civil na definição e no acompanhamento das políticas agrárias, pois assim as políticas públicas terão mais legitimidade e estarão mais próximas da realidade amazônica.

\subsection{TERRA DEVOLUTA E A LEGISLAÇÃO BRASILEIRA}

As terras devolutas são institutos jurídicos originários do direito brasileiro, não possuindo outro correspondente no direito internacional. De fato, é uma situação anômala da situação fundiária brasileira. Segundo o art. $5^{\circ}$. do Decreto-Lei $n^{\circ} .9 .760 / 46$, são devolutas na faixa de fronteira, nos territórios federais e no Distrito Federal, as terras que, não sendo próprias nem aplicadas a algum uso federal, estadual, territorial ou municipal, não se incorporarem ao domínio privado: 
a) Por força da Lei $n^{\circ}$. 601, de 18/09/1850, Decreto $n^{\circ}$. 1.318, de 30/01/1854, e outras leis e decretos gerais, federais e estaduais;

b) Em virtude de alienação, concessão ou reconhecimento por parte da União ou dos Estados;

c) Em virtude de lei ou concessão emanada de governo estrangeiro e ratificado ou reconhecido, expresso ou implicitamente, pelo Brasil em tratado ou convenção de limites;

d) Em virtude de sentença judicial ou com força de coisa julgada.

Resumidamente, Hely Lopes Meirelles (1993, p. 455) afirma que as terras devolutas "são todas aquelas que, pertencendo ao domínio público de qualquer das entidades estatais, não se acham utilizadas pelo Poder Público, nem destinadas a fins administrativos específicos. São bens públicos patrimoniais ainda não utilizados pelos respectivos proprietários.”

O Governo Federal admite que, na Amazônia, cerca de 24\% das terras estão sob apropriação privada ${ }^{1}, 31 \%$ são áreas públicas protegidas (sendo que $21 \%$ são áreas indígenas e 10\% são compostas por unidades de conservação) e 45\% são terras públicas devolutas, o que representa, aproximadamente, 235 milhões de hectares na Amazônia Legal.

Devido ao descontrole sobre o patrimônio público e pelo fato de o cadastro de imóveis rurais privados não ser confiável, os números apresentados não são fidedignos. De fato, o número de terras devolutas é menor do que o apresentado pelo Governo, pois na década de 1970 e 1980 diversas áreas foram arrecadadas ou discriminadas. Segundo a CPI da Grilagem de Terra (BRASIL, 2002, p. 546), entre 1985 e 1994 foram discriminados e/ou arrecadados 6.966.922 ha de terras devolutas. Somente uma análise gleba por gleba permite saber exatamente quais áreas podem ser denominadas como patrimônio fundiário próprio e, portanto, não devoluto, quais áreas são devolutas e quais estão sob o domínio privado.

Outro ponto a ser lembrado é que, além das terras devolutas, há também os terrenos de marinha, as áreas de várzea e os leitos de rios e lagos, que são terras públicas não devolutas.

Os terrenos de marinha sempre foram partes integrantes da propriedade do Estado, desde o Aviso de 27 de abril de 1826. Terrenos de marinha "são todos os que, banhados pelas águas do mar ou dos rios navegáveis, vão até a distância de 15 braças craveiras (33 metros) para a parte da terra, contadas desde o ponto a

1 É difícil afirmar que se trata de domínio privado porque não é fácil comprovar se todos os títulos registrados em cartórios são legítimos, por isso preferimos dizer "apropriação", que envolve áreas legitimáveis e áreas ilegais. 
que chega o preamar médio [de 1831]" (OCTAVIO, 1924, p. 147)². A Constituição Federal de 1988 ratifica a dominialidade pública federal em seu art. 20, VII.

A sua natureza jurídica é a que incide no terreno da calha alargada ou maior de um rio. A dominialidade é pública, podendo ser da União ou dos Estados, dependendo da propriedade das águas. Se o recurso hídrico pertencer à União, a várzea será federal; se a corrente d'água for estadual, ela será estadual, pois o álveo e o leito alargado dos rios seguem a mesma natureza do domínio das águas. A várzea não se confunde com as terras devolutas, pois aquele terreno é aplicado a um uso público, ou seja, tem uma destinação, que é dar suporte à água.

A partir da Constituição Federal de 1988, “as ilhas fluviais e lacustres nas zonas limítrofes com outros países; as praias marítimas; as ilhas oceânicas e as costeiras, excluídas destas as áreas referidas no art. 26, II"33 (art. 20, IV da CF), são bens da União. As ilhas fluviais e lacustres não pertencentes à União são bens dos Estados (art. 26, III da CF). Logo, as ilhas cuja dominialidade não foi transferida ao patrimônio privado pertencem ao Poder Público, seja ele federal ou estadual.

Com a Constituição de 1988, a água passou a ser considerada um bem público. A Lei n ${ }^{\circ}$ 9433/97 instituiu a Política Nacional de Recursos Hídricos e o Sistema Nacional de Gerenciamento de Recursos Hídricos. Essa Lei afirma que a água é um bem de domínio público ${ }^{4}$, sendo considerado um recurso natural limitado e em situação de escassez; o uso prioritário é o consumo humano e a dessedentação de animais. Logo, as águas serão sempre públicas; já não há, portanto, águas particulares ${ }^{5}$.

Como a água é um bem de domínio público, o terreno que a suporta, o álveo e o leito maior sazonal, também o são. Logo, as águas e o respectivo solo que elas ocupam (permanente ou sazonalmente) pertencem aos Estados quando

2 O próprio autor explica o que significa a expressão navegável, devendo "ser entendida em sua acepção mais larga como tal, considerando-se aqueles rios e lagos que permitam a flutuação por jangada, mesmo sem admitirem a passagem de barcos que demandem outro calado de água" (OCTAVIO, 1924, p. 76).

3 Afirma o art. 26, II da CF que se incluem entre os bens dos Estados: "as áreas, nas ilhas oceânicas e costeiras, que estiverem no seu domínio, excluídas aquelas sob domínio da União, Município ou terceiros".

4 A expressão domínio público é empregada no sentido de designar os bens destinados a um fim público, os quais compreendem os de uso comum do povo e os de uso especial. Como muito bem lembra DI PIETRO (2001, p. 531), “embora a classificação adotada pelo artigo 98 do Código Civil abranja três modalidades de bens, quanto ao regime jurídico existem apenas duas", ou seja, os bens do domínio público do Estado e os bens do domínio privado do Estado (os bens dominicais), sendo estes parcialmente públicos e parcialmente privados.

5 O Código Civil de 2002, em seu artigo 1.230, afirma que "a propriedade do solo não abrange as jazidas, minas e demais recursos minerais, os potenciais de energia hidráulica, os monumentos arqueológicos e outros bens referidos por leis especiais". Apesar de não constar no rol do caput do artigo citado, a Constituição Federal e a lei especial (Lei n . 9.433/97) excluíram a água da dominialidade privada. 
as águas, em suas diversas maneiras de manifestações, desde que não se encontrem em terrenos de propriedade da União, não banhem mais de um Estado (CF/88, art. 20, II), ou, quando em depósito, não decorram de obras realizadas pela União.

O terceiro passo para superar essa incerteza fundiária é elaborar um mapa, apresentando as áreas discriminadas, arrecadadas e as que ainda são terras devolutas. Os órgãos públicos estaduais e federais devem divulgar quais são as áreas devolutas da região amazônica para serem protegidas. Os juízes devem ser informados sobre essas áreas, a fim de não reconhecer títulos de terra em áreas públicas. O Poder Público se nega a dar essa informação, alegando que as glebas devolutas serão invadidas. Na prática, as terras devolutas estão sendo apropriadas indevidamente por um grupo minoritário que tem acesso privilegiado aos dados governamentais. É preciso "publicizar" as informações, a fim de interromper a grilagem e possibilitar à sociedade civil colaborar na proteção do patrimônio público (BENAT'TI et. al., 2006, p. 60).

\subsubsection{AS TERRAS DEVOLUTAS E SUA DOMINIALIDADE}

Incluem-se entre os bens do Estado as terras devolutas não pertencentes à União e os rios que tenham nascentes e foz em terras estaduais.

As terras devolutas se diferenciam das terras pertencentes ao patrimônio público mesmo que as duas sejam consideradas bens públicos, pois as terras devolutas são aquelas que não se acham aplicadas a algum uso público federal, estadual ou municipal, que não tenham sido legitimamente incorporadas ao domínio privado (Art. $5^{\circ}$., do Decreto-Lei nº 9.760/46). Já as terras públicas, pertencentes ao patrimônio fundiário público, são aquelas que estão inscritas e destinadas para algum fim, seja para preservação ambiental ou para reforma agrária.

Com a revogação do Decreto-Lei $n^{\circ} .1 .164$ de $1^{\circ}$ de abril de 1971, as terras devolutas, que estavam sob a jurisdição federal, voltaram para o Estado e foram incorporadas ao patrimônio do Estado; e as glebas de terras foram discriminadas, arrecadadas e até registradas, mas não foram destinadas pelo órgão fundiário federal, pois se entendeu que a consolidação destas áreas ao patrimônio público federal ocorreria com a destinação, já que os demais atos administrativos têm como objetivo reservar para determinado fim, seja ele para assentamento rural ou para preservação ambiental. Os casos que se enquadram nesta hipótese basta o Incra fazer a transferência para o Estado do Pará, por meio de convênio.

O Decreto-Lei n ${ }^{\circ} .2 .375$, de 24 de novembro de 1987, que revogou o Decreto-Lei n ${ }^{\circ}$.1.164/71, afirma no seu Art. 50. que "a União transferirá, a título gratuito, ao respectivo Estado ou Território, terras públicas não devolutas que, 
José Heder Benatti / Edna Castro / Thomas Hurtienne / Roberto Araújo de Oliveira Santos / Raimunda Nonata Monteiro da Silva / Roselene de Souza Portela

nas faixas mencionadas no caput do Art. $1^{\circ}$., lhe pertençam, condicionada, a doação, a que seu benefício vincule o uso daquelas áreas aos objetivos do Estatuto da Terra e legislação conexa." Portanto, a única obrigação para a transferência é a condição de que seu uso seja previsto na legislação agrária e nas demais normas positivas conexas.

Quanto às terras devolutas existentes no Pará, essas glebas de terra estão sob a jurisdição do Estado, pois, desde a Constituição Federal de 1891, Art. 64, a União transferiu o domínio delas para os Estados. Esta situação ficou inalterada até o advento do Decreto-Lei $n^{\circ}$. 1.164/71. Contudo, com a revogação desse Decreto-Lei em 1987, voltamos ao status quo jurídico de 1962.

O domínio das terras devolutas não está condicionado a sua demarcação, pois a falta de demarcação não exclui o domínio estadual. Poderia, quando muito, trazer uma certa dúvida, como a de saber se certa parcela de terreno está dentro ou fora da área concedida ao Estado. Por outro lado, seria um contra-senso fazer essa exigência, pois, além de não existir lei que imponha essa obrigação, no momento em que o governo estadual arrecada, demarca e matricula em seu nome uma área de terra devoluta, esta deixa de ser terreno devoluto para se tornar propriedade pública. Logo, o que se pode inferir é que a demarcação seja um encargo do Estado, mas não uma condição para assegurar seu domínio sobre as terras devolutas.

De acordo com a Constituição Federal, a destinação das terras devolutas deve ser compatibilizada com a política agrícola e com o plano nacional de reforma agrária (Art. 188), assim como deve servir para a proteção dos ecossistemas naturais (Art. 225, Parágrafo 5.). O art. 13 da Lei n ${ }^{\circ}$ 8.629, de 25 de Fevereiro de 1993, determina que as terras de domínio dos Estados devem ser destinadas, preferencialmente, à execução de planos de reforma agrária. As exceções a esta regra geral são reduzidas: criação de unidades de conservação, de projetos de pesquisa e fomento, áreas de segurança, treinamento militar, educação e defesa nacional. O órgão fundiário estadual ou federal terá plena legitimidade de trabalhar priorizando a preservação ambiental ou os assentamentos de trabalhadores rurais sem terra, até o limite máximo de 500 ha.

Assim, podemos classificar as áreas públicas em:

a) Áreas Institucionais: são os terrenos de marinha e terrenos marginais e seus acrescidos, áreas pertencentes ao Patrimônio da União, por força da Lei $n^{\circ}$. 9.636 de 15 de maio de 1998, que dispõe sobre a regularização, administração, aforamento e alienação de bens imóveis de domínio da União, altera dispositivos dos Decretos-Leis $\mathrm{n}^{\circ}$. 9.760, de 5 de setembro de 1946, e $\mathrm{n}^{\circ} .2 .398$, de 21 de dezembro de 1987, regulamenta o $\int 2^{\circ}$. do Art. 49, do Ato das Disposições Constitucionais 
Transitórias. Neste caso iremos encontrar no Pará somente os terrenos marginais estadual e federal, dependendo se o rio for estadual ou federal;

b) Terras Indígenas: reconhecidas oficialmente, homologadas, delimitadas, regularizadas, reservadas, interditadas, não reconhecidas oficialmente, em identificação, e as sem providência. Essas terras, por definição constitucional, pertencem à União;

c) Unidades de Conservação: criadas pela União, pelo Estado e, se for o caso, pelos municípios. Pertencem ao Pará as Unidades de Conservação criadas pelo governo estadual;

d) d) Áreas abrangidas pelo Decreto-lei n . 1.164, de 01.04.1971: conforme discutido anteriormente, pertencem ao Estado do Pará as terras abrangidas pelo Decreto $n^{\circ} .1 .164 / 71$, que se encontram nas seguintes situações: i) as devolutas; e ii) as áreas discriminadas, arrecadas e até matriculadas, mas que não foram destinadas para fins de reforma agrária pelo Incra.

e) Áreas pertencentes aos Ministérios do Exército, Aeronáutica ou às Forças Armadas: as áreas relacionadas no Decreto $n^{\circ} .95 .859$, de 22 de março de 1988, que diz respeito ao uso especial do Exército, terras referidas no Art. $3^{\circ}$. e $\int 1^{\circ}$, do Decreto-lei n .2 .375 , de 24 de novembro de 1987; e no Decreto ${ }^{\circ}$. 97.596, de 30 de março de 1989, que diz respeito ao uso especial do Exército, terras públicas federais, referidas no Art. $2^{\circ}$. do Decreto n .95 .859 , de 22 de março de 1988, não incidem em terras do Estado do Pará. Logo, as possíveis terras constantes no Decreto $n^{\circ}$. 2.180/97, que pertenciam às Forças Armadas e foram transferidas ao Incra, estão fora da área jurisdicional do Estado.

f) A Faixa de Fronteiras Internacionais no Estado do Pará: o Art. $5^{\circ}$., \& $1^{\circ}$. do Decreto-Lei $n^{\circ}$. 2.375/87 prevê a possibilidade de a União transferir aos Estados as terras localizadas na Faixa de Fronteira, desde que vincule o uso destas áreas aos objetivos do Estatuto da Terra e da legislação conexa e respeitadas as condições impostas nos parágrafos $2^{\circ}$. e $3^{\circ}$. deste Decreto. De fato, o Art. 20, $\mathbb{S}$ $2^{\circ}$. da Constituição Federal recepcionou o Decreto-Lei supracitado como também a Lei $n^{\circ}$. 6.634/79.

\subsection{REGULARIZAÇÃO FUNDIÁRIA E PROPRIEDADE FAMILIAR $^{6}$}

Um dos pontos de pauta do ordenamento territorial na Amazônia é a discussão sobre a regularização fundiária e a institucionalização da propriedade privada (individual e coletiva). A implementação de políticas públicas que assegurem o 6 Parte das idéias aqui desenvolvidas foi apresentada no trabalho "A grilagem de terras públicas na Amazônia brasileira” (BENATTI et. al., 2006). 
José Heder Benatti / Edna Castro / Thomas Hurtienne / Roberto Araújo de Oliveira Santos / Raimunda Nonata Monteiro da Silva / Roselene de Souza Portela

direito à terra é uma pré-condição para a consolidação de um modelo democrático e participativo de distribuição e gestão da terra e dos recursos naturais, pois o reconhecimento do direito de propriedade é um "pressuposto dos direitos de participação política” (MARTINÉZ, 1994, p. 157).

Quando referimos a regularização fundiária não estamos legitimando qualquer tipo de apropriação privada. O reconhecimento do direito de propriedade privada em terras públicas está vinculado a uma apropriação individual ou coletiva da terra, compatível com a função socioambiental.

O quarto passo na discussão da regularização fundiária é garantir o acesso para o desenvolvimento das diferentes atividades sociais e econômicas; as propriedades ficam comprometidas em cumprir a sua função social e ambiental. Assim, o acesso plural à terra e a função social da propriedade são duas manifestações das cláusulas do Estado democrático. Não se pode implementar uma sem assegurar a efetividade da outra.

A importância da garantia do direito de propriedade, com essas duas dimensões, está no fato de reconhecer o direito à terra às comunidades indígenas, às populações tradicionais, aos camponeses e aos médios e grandes posseiros ${ }^{7}$. Ao mesmo tempo em que se reconhece um direito, estão-se definindo deveres, pois se possibilita que a propriedade tenha um limite reconhecido, um cadastro confiável, o uso da terra e dos recursos naturais legalizado e monitorado. Reconhece-se o espaço de manifestação de liberdade do indivíduo ou da coletividade e, concomitantemente, assegura-se que o exercício da autonomia privada esteja sujeito à função social e ambiental da propriedade privada rural.

Outro ponto importante neste debate é a priorização para a destinação das terras públicas. Os comandos constitucionais e infraconstitucional (artigos 3º., III; 184 e 188 da CF e o artigo 13 da Lei n ${ }^{\circ}$ 8.629/93, respectivamente) determinam que as terras rurais de domínio da União, dos Estados e dos Municípios fiquem destinadas, preferencialmente, à execução de planos de reforma agrária. As demais glebas de terras que não se enquadrarem nesses critérios podem ser destinadas para a média e grande propriedade, respeitado o limite máximo do módulo rural constitucional.

As glebas de terras para proteção ambiental possuem uma sistemática própria, prevista na Lei nº 9.985/2000 (Lei do Sistema Nacional de Unidade de Conservação (SNUC)), e quando houver sobreposição de interesses, a destinação ambiental acaba se sobrepondo às demais destinações agrárias (artigo 225, $\sqrt{ } 5^{\circ}$.

7 Definimos como grande posseiro, para fim de regularização fundiária, a faixa de ocupação com base na Lei Agrária e na Constituição Federal, ou seja, acima de 15 módulos fiscais e abaixo de 2.500 ha. Acima de 2.500 ha continua sendo um grande posseiro, mas a competência para deliberar sobre a regularização fundiária é do Congresso Nacional, conforme mandamento constitucional. 
da CF). O mesmo raciocínio cabe para as áreas indígenas, que também possuem uma sistemática própria, já consolidada na estrutura administrativa do Executivo Federal.

Lembramos, ainda, que, além dos aspectos agrários da regularização fundiária, é necessário incluir comandos normativos que dizem respeito ao meio ambiente, como elementos necessários para a legitimação da posse. Nessa linha, estão os artigos $6^{\circ}$. e $7^{\circ}$. do Decreto $n^{\circ} .1 .282$, de 19 de outubro de 1994, ao introduzirem obrigações ao legítimo ocupante de terras públicas que explore recursos florestais. Uma das obrigações é a determinação de que somente será permitido o manejo florestal ou a exploração a corte raso da floresta e das demais formas de vegetação arbórea da bacia amazônica, se houver licenciamento ambiental. A outra determinação legal refere-se à proteção da área de preservação permanente e da reserva legal.

Não é demais afirmar que, se ocorrer conflito de interesses em uma mesma área, os que têm direito de preferência na regularização fundiária são: primeiro, as posses tradicionalmente ocupadas pelos índios e pelas comunidades de quilombolas; em segundo lugar, as áreas necessárias à proteção dos ecossistemas naturais e as ocupadas pelas populações tradicionais; em terceiro lugar, as glebas de terras destinadas à reforma agrária (propriedade familiar) e, por último, as glebas para as atividades agroambientais (agricultura, pecuária, extrativismo ou misto), para imóveis médios e grandes.

\subsection{A REGULARIZAÇÃO FUNDIÁRIA E OS PROJETOS DE ASSENTAMENTOS}

Um dos equívocos do debate sobre a regularização fundiária e a criação de projetos de assentamentos é primeiro definir a modalidade de assentamento - projeto de assentamento (PA), projeto de assentamento agroextrativista (PAE) e projeto de desenvolvimento sustentável (PDS) - antes de definir o processo de regularização. Isso significa que primeiro se define o instrumento jurídico (tipo de assentamento) para depois adequar os elementos sociais e ambientais.

A nosso ver, deve-se analisar o processo de regularização fundiária, que envolve conhecer:

a) A formação social. A história de formação do grupo social que ocupou aquela área;

b) O grau de organização social, se possui instituição de representação social;

c) Como seus limites foram estabelecidos, e qual o tamanho da área; 
José Heder Benatti / Edna Castro / Thomas Hurtienne / Roberto Araújo de Oliveira Santos / Raimunda Nonata Monteiro da Silva / Roselene de Souza Portela

d) Como a população está distribuída na área. Se for concentrada ou dispersa;

e) Quantas famílias e indivíduos ocupam a área;

f) Qual é a formação étnica da população;

g) Como está se dando o uso da terra e dos recursos naturais (floresta, caça, recurso hídrico, mineral etc.);

h) O Ecossistema ocupado;

i) Trata-se de apossamento familiar ou de uso comum.

Após a definição dos itens acima enumerados, aos quais poderemos acrescentar outros para melhor compreensão da complexidade da ocupação humana em um determinado espaço natural, é que se discute o tipo de assentamento (PA, PAE ou PDS) ou unidade de conservação (reserva extrativista ou reserva de desenvolvimento sustentável) que será criada para assegurar o direito à terra.

Para a regularização fundiária em lotes familiares de até $500 \mathrm{ha}^{8}$, apresentamos os seguintes elementos (requisitos e direitos) necessários para a legitimação de posse:

a) Deve existir, manifestadamente, a posse da coisa, com animus domini;

b) Comprovar a cultura efetiva pelo prazo mínimo de um ano ininterrupto\%;

c) Não deve haver oposição de terceiros;

d) É permitido ao possuidor - tanto o universal quanto o singular -, para o fim de contar o prazo exigido, acrescentar sua posse à de seu antecessor, contanto que ambas sejam contínuas;

e) Não ser proprietário de outro imóvel rural em qualquer parte do território nacional;

f) Ser reconhecido esse direito ao mesmo possuidor uma única vez, exceto para o imóvel adquirido onerosamente;

g) Não ter sido beneficiado pelo Programa de Reforma Agrária, ressalvadas as situações admitidas pelo Incra;

\footnotetext{
8 Uma novidade introduzida recentemente é a que está prevista no art.120 da Lei nº 11.196 , de 21 de novembro de 2005, que permite ao Incra a concessão de uso da terra ou a titulação definitiva de lotes com até 500 ha na Amazônia Legal, sem precisar de licitação. Só serão beneficiados: a pessoa física que, nos termos de lei, regulamento ou ato normativo do órgão competente, haja implementado os requisitos mínimos de cultura e moradia; o imóvel situado em zona rural; e, exclusivamente, as áreas em que a detenção por particular seja comprovadamente anterior a $1^{\circ}$. de dezembro de 2004. Essa medida ajudará a resolver problemas existentes em assentamentos rurais na Amazônia e ampliará a área que pode ser regularizada sem licitação pública, que antes estava limitada a 100 ha. Esta Lei modificou parte do art. 17 da Lei no. 8.666/93, que regulamentou o art. 37, inciso XXI, da Constituição Federal, instituindo normas para licitações e contratos da Administração Pública. Especificamente, o art. 17 trata da alienação de bens da Administração Pública.

9 A cultura efetiva inclui as atividades agrícola, pastoril, extrativa ou mista.
} 
h) Possuir uma percentagem de área aproveitável do imóvel efetivamente utilizada, conforme o que estabelece a legislação ambiental, com o uso adequado dos recursos naturais e a proteção do meio ambiente; ${ }^{10}$

i) A pessoa física ou jurídica ${ }^{11}$ pode ser beneficiária de concessão de terras públicas federais.

As áreas reivindicadas em dimensão inferior ao módulo rural poderão ser acrescidas desde que haja disponibilidade de terras públicas federais vagas e confinantes, e não ultrapassem o módulo estabelecido para a região.

$\mathrm{Na}$ recuperação da área de preservação permanente e/ou de reserva legal, os ocupantes de terra com passivo ambiental deverão assinar o TAC para recuperar a cobertura vegetal desmatada.

Os projetos de assentamento, assim como as solicitações de legitimação de posses individuais, deverão ser acompanhados de planta e memorial descritivo georreferenciado, elaborados de acordo com a norma técnica para o georreferenciamento de imóveis rurais, editada pela Resolução Incra/CD n .10 , de 17 de novembro de 2003. Nesse caso, fica o Poder Público responsável por apresentar esses dados, após concluir o laudo de vistoria.

2 CICLO DE FRONTEIRA: A DIVERSIDADE DA AGRICULTURA FAMILIAR NA ÁREA DE ABRANGÊNCIA DA BR-163 PRINCIPAIS CARACTERÍSTICAS ESTRUTURAIS, TRAJETÓRIAS E DINÂMICAS

\subsection{DIFERENCIAÇÕES INTERNAS DA PEQUENA PRODUÇÃO NA SANTARÉM-CUIABÁ}

As categorias que seguem revelam a complexidade de situações e de atores nas áreas estudadas, com interesses, motivações e papéis bastante diferenciados na ocupação e uso da terra e no processo de desmatamento.

10 Além de o posseiro ou posseira ter a obrigação de proteger a área de preservação permanente, o $\int 10$ do Art. 16 do Código Florestal, com as alterações introduzidas pela MP nº. 2166-67/02, permite a criação da reserva legal em área de posse, ao estabelecer que "a reserva legal é assegurada por Termo de Ajustamento de Conduta, firmado pelo possuidor com o órgão ambiental estadual ou federal competente, com força de título executivo e contendo, no mínimo, a localização da reserva legal, as suas características ecológicas básicas e a proibição de supressão de sua vegetação, aplicando-se, no que couber, as mesmas disposições previstas neste Código para a propriedade rural."

11 A pessoa jurídica tratada nesse item é a associação ou cooperativa de pequenos produtores rurais. 
José Heder Benatti / Edna Castro / Thomas Hurtienne / Roberto Araújo de Oliveira Santos / Raimunda Nonata Monteiro da Silva / Roselene de Souza Portela

1. Colono sitiante (clássico): chegado no projeto inicial da colonização, ocupando módulos de 100 ha, assentados nas margens da rodovia, com estruturas familiares e comunitárias sólidas;

2. Migrante dos garimpos: grupo formado, geralmente, por homens que procuraram se estabelecer na agricultura após o declínio dos garimpos da bacia do Tapajós. Ocuparam alguns lotes das margens, mas, a maior parte, os menos capitalizados, ocuparam as vicinais.

3. Assentados pelo Incra: grupo formado por pequenos produtores assentados a partir de 1996, em Projetos de Assentamentos (PAs) que obedecem ao modelo conhecido na Amazônia como "Quadrado Burro": lotes de 100 ha, linearmente situados, sem condições de viabilidade.

4. Brasiguaios: pequenos produtores que perfizeram a trajetória de migração a partir da construção de Itaipu ou pela escassez de terras em outras regiões do Paraná, que trabalharam com soja no Paraguai e, nos últimos anos, fracassados, procuram terras mais baratas na Santarém-Cuiabá com o objetivo de se estabelecerem como pequenos pecuaristas.

5. Colonos retornantes: sitiantes que abandonaram os lotes nos períodos críticos de intrafegabilidade da rodovia e estão retornando com a possibilidade de asfaltamento e valorização da região.

6. Posseiros (aspirantes a produtores): chegam todos os dias em todas as cidades da rodovia, vindos do Maranhão, do Tocantins e, principalmente, do Mato Grosso. Procuram os Sindicatos de Trabalhadores Rurais (STRs), as prefeituras e as empresas em busca de terra e emprego.

Os colonos que chegaram no início da ocupação são uma minoria e, aparentemente, estão mais fortes onde conseguiram ficar juntos numa mesma sub-região. É o caso das comunidades de São José, Linha Gaúcha e Santo Antônio, a $55 \mathrm{~km}$ da cidade de Novo Progresso, ao norte da Santarém-Cuiabá. Estão, em sua maioria há mais de vinte anos, onde formaram lotes em torno de 200 ha, com pequena pecuária e cultivos diversificados, principalmente para a subsistência. Estão organizados em comunidades e em associações de produtores. A relativa estabilidade econômica e a estrutura de trabalho baseado na mão-de-obra familiar vêm permitindo a permanência na terra, mas dificilmente a reprodução social das famílias com esse perfil.

Os filhos desses agricultores não têm no ideal de sitiantes o seu projeto de vida. A maioria estudou até a quarta ou a oitava série e gostaria de continuar os estudos e ter outra profissão. Mesmo os que querem se manter na atividade teriam hoje a restrição do espaço para desenvolver suas atividades, pois as terras 
de seus pais estão sendo cortejadas por compradores de terras do Mato Grosso. Filhos que estão casados já combinam o trabalho nas propriedades com o serviço assalariado. Esses produtores são encontrados também em Trairão, em poucas propriedades na margem da rodovia. Também estão próximos entre si, porém cercados por grandes propriedades.

A organização social desses produtores é diferenciada em cada município. Em Itaituba, fazem parte do STR, junto com assentados dos PA's do Incra; em Trairão, eles estão mais presentes na Associação dos Produtores de Cacau, sendo que o STR representa mais os produtores dos PA’s. Em Novo Progresso, eles são, em sua maioria, organizados pela Associação dos Produtores ligada à Faepa. Os sitiantes mais fortes são organizados em associações locais. O STR tem, entre seus sócios, assentados dos PA’s, brasiguaios e colonos sitiantes; em Castelo dos Sonhos, o STR congrega principalmente os assentados dos PA's e aspirantes a produtores.

\subsection{MOVIMENTO NO ESPAÇO}

Cada segmento tem um tipo próprio de movimentação no espaço que tem que ser visto nas estruturas delineadas, mais determinantemente, nos últimos 50 anos no espaço agrário do país.

Os estados de origem dos pequenos produtores que migraram para a BR-163, que passou por um intenso processo de concentração da terra, a partir da década de 1950, eram Rio Grande do Sul, Paraná e Mato Grosso do Sul. No Centro-Sul, a política oficial incentivou a urbanização colada a uma industrialização centrada na produção de bens de consumo duráveis.

A indústria de maquinários agrícolas dava suporte para uma política de industrialização da produção agrícola, incompatível com os padrões e sistemas de produção dos pequenos produtores. No Nordeste, as estruturas oligárquicas de propriedade da terra se ampliaram, intensificando a transferência de mão-de-obra para a indústria do Centro-Sul e, a partir da década de 1970, substancialmente, para as oportunidades abertas com os Grandes Projetos minerais e de infra-estrutura na Amazônia.

Essas dinâmicas ocasionaram diferentes movimentos migratórios no rumo do interior do país, sendo que, a partir da década de 1960, foram diretamente incentivados pelo governo federal. As trajetórias descritas abaixo, encontradas na BR-163, são a continuidade das macrodinâmicas vivenciadas no país. 
Figura 1: Rotas dos colonos sitiantes e brasiguaios

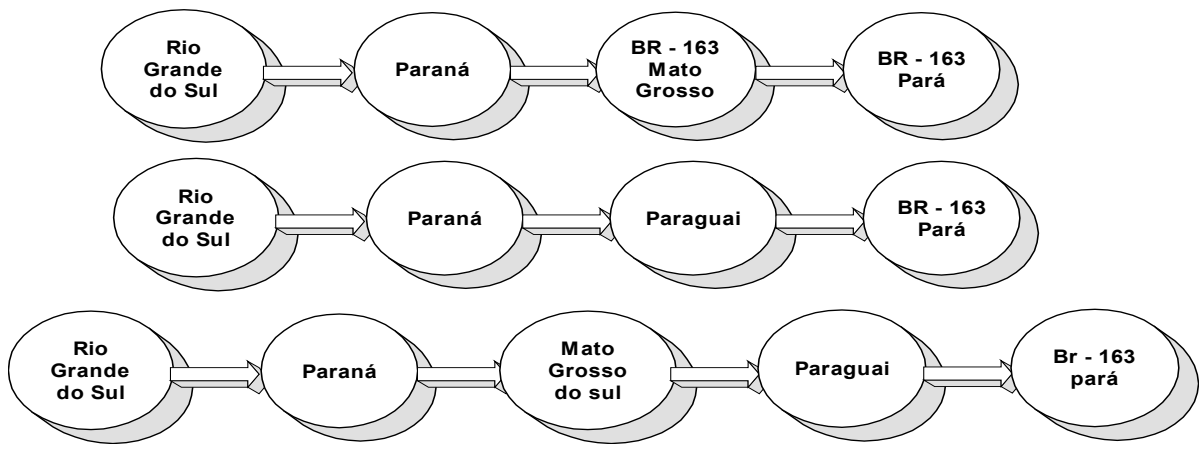

Fonte: CASTRO; MONTEIRO; CASTRO, 2004.

Estão representadas, na figura 2, as diversas origens da população de trabalhadores daquela região que seguiram, na história recente da Amazônia, a trilha das empreiteiras dos grandes projetos, das empresas de madeira e de garimpo, dos programas de colonização, ou vieram por conta própria para aventurar terra e/ou trabalho.

Figura 2: Migrantes dos garimpos

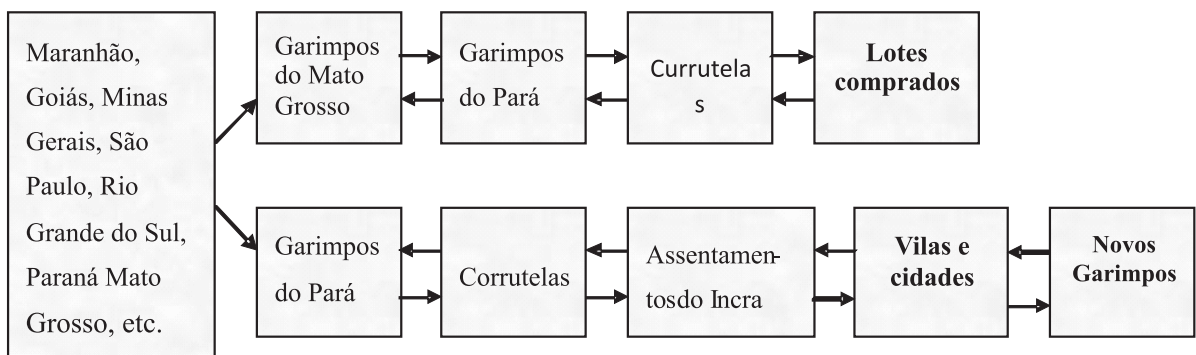

Fonte: CASTRO; MONTEIRO; CASTRO, 2004.

$\mathrm{Na}$ atividade garimpeira, aparentemente se repetem diferenciações sociais vistas em outras atividades. A maior parte da mão-de-obra não qualificada vem do Nordeste, enquanto a competência técnica e o controle das explorações ficam com pessoas originárias de estados que também tiveram tradição de mineração (Goiás, Minas, São Paulo, e mesmo Paraná). Em Itaituba, onde os garimpos de ouro precedem a BR-163, a dinâmica e a propriedade das explorações estão ligadas a grupos da própria região. 
Para os colonos sitiantes, a movimentação no espaço ocorre num tempo maior. Os que se estabeleceram no início da colonização e permanecem até hoje estão com suas pequenas propriedades estruturadas e a perspectiva de migração pode vir a ocorrer pelas seguintes razões geracionais: i) os filhos não desejam prosseguir na atividade e nem no local ou os velhos começam a precisar de assistência médica e necessitam morar nas cidades; ii) isolamento produtivo e fundiário: os produtos diversificados não terão escala suficiente para uma organização produtiva mais forte, dificultando a relação com o mercado.

Mas pode acontecer também a viabilização desse setor, caso consiga as condições de infra-estrutura necessárias nas vilas em que se concentram, articulando atividades rurais e urbanas que ocupem os filhos e mantenham a atividade rural como base. Pela diversificação dos produtos, eles podem abastecer as cidades com alimentos como hortaliças, pequenos animais e derivados de leite. Os aglomerados que ficaram nas margens ou até $5 \mathrm{~km}$ da rodovia podem se afirmar numa política voltada para este fim. Isto pode ser observado entre Rurópolis ou Itaituba até Novo Progresso. Em Castelo de Sonhos, a predominância é dos migrantes de garimpos e dos novos pretendentes a produtores.

No caso dos brasiguaios, na origem da saída do Paraná, estão a implantação dos grandes cultivos de soja e a barragem de Itaipu. No Paraguai, alguns se estabeleceram como proprietários e hoje, conforme depoimentos, as terras que ocuparam estão sendo adquiridas por produtores de soja dos Estados Unidos. Foi relatado um grupo de 30 famílias que estão tentando comprar 10 mil alqueires no Crepurizão, junto ao Incra. Esses estão procurando terra para a soja, o que já faziam no Paraguai. A terra, nessa região, custa $\mathrm{R} \$ 40,00$ o alqueire.

Os migrantes dos garimpos, de acordo com as observações, teriam mais dificuldade de se estabelecer. Suas trajetórias levaram à perda dos vínculos com a terra, em certos casos, por mais de uma geração. A terra é uma oportunidade que tem uma função de aventura, uma possibilidade de "bamburro" 12 . Para eles, ganhar a terra e a casa em um assentamento já é um bamburro, assim como poder vender a madeira do lote, associando a venda à manutenção da estrada. Mas, quando acaba a madeira e a remuneração do trabalho passa a depender apenas da agricultura de subsistência possível sem nenhuma assistência, então o assentamento perde o sentido. Acaba-se a madeira, as empresas só mantêm a estrada se ela der acesso a outras explorações. Sem escola e sem assistência médica, o movimento no espaço se inverte e essa mão-de-obra errante sai em busca de outros pequenos, eventuais e virtuais bamburros.

12 "Bamburrar" significa achar muito ouro, compensar as dificuldades da busca e do investimento feito. 
Os assentados do Incra vêm dos garimpos, mas podem fazer parte das levas de mão-de-obra que estão se movimentando atrás da migração da atividade madeireira que chega ao Pará, com a expectativa de que aqui poderão ser proprietários de terra. O sonho da pecuária move muitas dessas trajetórias como referencial de sucesso econômico, de acordo com o quadro 1.

Quadro 1: Principais Projetos de Assentamentos identificados

\begin{tabular}{|c|c|c|c|}
\hline Municípios & $\begin{array}{c}\text { Projetos de } \\
\text { Assentamento }\end{array}$ & Caracterização & Conflitos \\
\hline $\begin{array}{l}\text { Itaituba / } \\
\text { Trairão / } \\
\text { Rurópolis }\end{array}$ & AREIAS & $\begin{array}{l}\text { Situa-se a } 33 \mathrm{~km} \text { da cidade de } \\
\text { Trairão, onde foi assentada uma } \\
\text { comunidade assistida pelos ma- } \\
\text { deireiros. }\end{array}$ & $\begin{array}{l}\text { Manoel Joaquim Cavalcante } \\
\text { seria o representante do Grupo } \\
\text { de Osmar Ferreira na área. Co- } \\
\text { locaram porteira para impedir a } \\
\text { entrada e saída dos moradores } \\
\text { do assentamento. A PF abriu as } \\
\text { porteiras, mas os assentados são } \\
\text { obrigados a vender a madeira } \\
\text { dos seus lotes para o grupo. É } \\
\text { uma forma de manutenção de } \\
\text { mão-de-obra cativa e de controle } \\
\text { do preço da madeira. }\end{array}$ \\
\hline Trairão & $\begin{array}{l}\text { PROJETORIO } \\
\text { BONITO }\end{array}$ & $\begin{array}{l}\text { Iniciado em } 1995 \text {. Quando co- } \\
\text { meçou já tinha gente morando } \\
\text { dentro, mas sem documentos. } \\
\text { Há } 20 \mathrm{~km} \text { de Trairão, no mu- } \\
\text { nicípio de Altamira não tem } \\
\text { estrada. Existem mais de } 124 \\
\text { assentados, dos quais } 70 \% \text { estão } \\
\text { sem estrada. Foi feito crédito de } \\
\text { fomento do Incra para menos da } \\
\text { metade dos assentados. Muitos } \\
\text { saíram e afirmam que voltam } \\
\text { quando tiver infra-estrutura. Os } \\
\text { lotes mais distantes estão sendo } \\
\text { vendidos por R } \$ 300,00 / 500,00 \text {. } \\
\text { Fala-se de Osmar Ferreira (o rei } \\
\text { do mogno em S. Félix do Xingu) } \\
\text { como dono das empresas madei- } \\
\text { reiras que mantêm as estradas e a } \\
\text { exploração da madeira na área. } \\
\text { Dos } 124 \text { assentados do Rio } \\
\text { Bonito, } 25 \text { estão trabalhando } \\
\text { em lotes da margem da estrada, } \\
\text { guardando os lotes dos assenta- } \\
\text { mentos para os filhos. Nesses } \\
\text { casos, os lotes funcionam como } \\
\text { uma poupança e, como tal, um } \\
\text { risco, pois a pressão sobre essas } \\
\text { terras é grande. }\end{array}$ & $\begin{array}{l}\text { Os conflitos estão sendo confi- } \\
\text { gurados. Pelo menos cinco pre- } \\
\text { tensos a grandes proprietários } \\
\text { estão se acercando, todos com } \\
\text { uma área já dentro do assenta- } \\
\text { mento }{ }^{1} \text {. Alguns são conhecidos } \\
\text { do local, outros não. O mercado } \\
\text { de terras funciona baseado na } \\
\text { ilegalidade }{ }^{2} \text { envolvendo gran- } \\
\text { des e pequenos numa disputa } \\
\text { desigual. }\end{array}$ \\
\hline
\end{tabular}




\begin{tabular}{|c|c|c|c|}
\hline $\begin{array}{l}\text { Novo Pro- } \\
\text { gresso }\end{array}$ & $\begin{array}{l}\text { NOVA FRON- } \\
\text { TEIRA }\end{array}$ & $\begin{array}{l}\text { Iniciado em } 1997 . \text { A maioria dos } \\
\text { assentados é proveniente dos ga- } \\
\text { rimpos. Está situado a } 55 \mathrm{~km} \text { ao } \\
\text { norte de Novo Progresso, com } \\
\text { mais dez km na vicinal. São lotes } \\
\text { de } 80 \text { ha com } 200 \text { assentados. } \\
\text { É assistido pelos madeireiros } \\
\text { na manutenção das estradas, } \\
\text { em troca vendem a madeira } \\
\text { dos lotes. }\end{array}$ & $\begin{array}{l}\text { O principal conflito refere-se } \\
\text { à acusação de que o prefeito } \\
\text { anterior teria desviado R } \$ 119 \\
\text { mil do assentamento Santa Júlia, } \\
\text { um assentamento de sua família, } \\
\text { como estratégia de concentração } \\
\text { de } 4.500 \text { ha terras. No caso de } \\
\text { Nova Fronteira, a principal } \\
\text { queixa também é em relação } \\
\text { ao referido prefeito, que teria } \\
\text { desviado recursos das estradas, } \\
\text { deixando os assentados no } \\
\text { abandono. A madeireira Taiga, } \\
\text { que possui placas por dezenas de } \\
\text { quilômetros na rodovia, também } \\
\text { estaria ameaçando as terras do } \\
\text { assentamento. }\end{array}$ \\
\hline $\begin{array}{l}\text { Novo Pro- } \\
\text { gresso }\end{array}$ & $\begin{array}{l}\text { SANTA JÚ- } \\
\text { LIA } \\
\text { PA }\end{array}$ & $\begin{array}{l}\text { Situado a } 50 \mathrm{~km} \text { a norte de Novo } \\
\text { Progresso, tem cerca de } 300 \\
\text { assentados. Não tem posto de } \\
\text { saúde e nem escolas e as estradas } \\
\text { são mantidas também por madei- } \\
\text { reiros. A entrada da vicinal Santa } \\
\text { Júlia é uma vila madeireira. }\end{array}$ & $\begin{array}{l}\text { Envolve o presidente da associa- } \\
\text { ção do assentamento que estaria } \\
\text { envolvido na venda das terras. } \\
\text { Pecuaristas seriam os principais } \\
\text { compradores. Não tem posto } \\
\text { de saúde e nem escolas e as } \\
\text { estradas são mantidas também } \\
\text { por madeireiros. }\end{array}$ \\
\hline \multirow[t]{2}{*}{$\begin{array}{l}\text { Novo Pro- } \\
\text { gresso }\end{array}$} & $\begin{array}{l}\text { GLEBA GO- } \\
\text { ROTIRE }\end{array}$ & $\begin{array}{l}\text { Cerca de } 80 \text { posseiros estão } \\
\text { reivindicando do Incra uma área } \\
\text { que, nos mapas da instituição, } \\
\text { aparece com nomes de grupos } \\
\text { empresariais ou de pessoas do } \\
\text { Centro-Sul. São áreas de, em } \\
\text { média, } 6.500 \text { ha. Está situada } \\
\text { a } 40 \mathrm{~km} \text { da cidade, no sentido } \\
\text { norte da BR-163 até a vicinal de } \\
\text { entrada. Na vicinal tem mais } 30 \\
\text { km a Leste, no rio Jamanxim. }\end{array}$ & $\begin{array}{l}\text { Os posseiros chegam princi- } \\
\text { palmente do Mato Grosso e } \\
\text { procuram o STR ou a agência } \\
\text { de emprego. São listados e a } \\
\text { demanda é levada ao Incra. Na } \\
\text { semana da visita estavam entran- } \\
\text { do de } 30 \text { a } 40 \text { famílias por dia na } \\
\text { Gleba. O conflito é iminente e } \\
\text { as ameaças de morte contra o } \\
\text { delegado sindical do município } \\
\text { são constantes. }{ }^{3} \text { O STR calcula } \\
\text { que chegam ônibus e caminhões, } \\
\text { trazendo de } 2 \text { a } 3 \text { mudanças } \\
\text { todos os dias. }\end{array}$ \\
\hline & $\begin{array}{l}\text { R E S E R V A } \\
\text { I N D I G E - } \\
\text { N A B A Ú / } \\
\text { MEKRANO- } \\
\text { TIRE }\end{array}$ & $\begin{array}{l}\text { Poucas informações dão conta } \\
\text { de que posseiros estariam inva- } \\
\text { dindo a terra indígena. }\end{array}$ & \\
\hline
\end{tabular}

Fonte: CASTRO; MONTEIRO; CASTRO, 2002. 


\subsection{PROBLEMAS ENCONTRADOS PELOS PROJETOS DE ASSENTAMENTOS DO INCRA (PA'S)}

\section{Localização}

Estão distantes do mercado, em condições de elevado custo de serviços públicos e, geralmente, situados em áreas já pretendidas seja por madeireiros informações sobre o estoque existente - seja por pecuaristas (áreas para expansão de pecuária). Ocorre de as áreas serem pretendidas pelos dois e, ultimamente, principalmente em Santarém, também pretendidas por produtores de grãos.

O elevado custo de atendimento de saúde e educação tem levado o Incra e as universidades brasileiras a promoverem uma educação específica para os Projetos de Assentamento por meio do PRONERA. Os PA's, nessa lógica, mantêm uma característica de espaços sociais abstraídos das realidades locais e regionais em que se situam, objetos permanentes e dependentes de políticas especiais desconectadas dos compromissos públicos locais e estaduais. São espaços estranhos e extraordinários e, por isso mesmo, fadados a uma dependência estrutural que não lhes assegura sustentabilidade no tempo e no espaço.

As localizações determinam as alianças dos assentados com os madeireiros que chegam primeiro para explorar a madeira, dando em "troca" a abertura e a manutenção de estradas que duram o tempo de exploração do estoque. Casos como o da Marflops, em Santarém, indicam uma modalidade mais sofisticada de terceirização dos serviços públicos para uma empresa privada em que a empresa recebe do Incra o dinheiro para a manutenção das estradas e os assentados fazem um contrato de exclusividade da venda da madeira à empresa. A exclusividade da venda embute o capital tecnológico da empresa que faz os planos de manejo para a extração da madeira. Uma tecnologia que deveria ser pública e disponível para os assentados fazerem seus negócios sem a tutela monopolista.

\section{Características naturais}

Solo, relevo e recursos hídricos. Essas pré-condições técnicas e ambientais, em geral, são desfavoráveis em Projetos de Assentamento. Em que medida essas condições fazem parte de um planejamento maquiavélico contra a reprodução social de uma agricultura em escala familiar merece mais estudos. Por outro lado, se resultarem do desconhecimento dos órgãos fundiários sobre essas bases de informações, o problema tem igual gravidade. Os estudos do Radam Brasil apresentam informações básicas que indicam essas características capazes de orientar decisões sobre os territórios amazônicos. 
Projetos de Assentamento em São Félix do Xingu, na Gleba Pacoval (Santarém-Prainha), no Norte do Mato Grosso e no Sudeste e Sudoeste do Pará demonstram que as áreas destinadas aos pequenos agricultores não obedecem a critérios técnicos voltados para a sua viabilidade, tornando-os vulneráveis ao processo de apropriação estrutural pelos setores mais capitalizados que podem pagar pelos custos de conversão dessas áreas, com a vantagem de não mais arcar com os custos de desmatamento.

São freqüentes as localizações dos PA’s em áreas degradadas de pastagens no Sudoeste Paraense, em áreas rochosas, montanhosas e sem água. Considerando a ausência também estrutural de assistência técnica, a permanência desses assentados em condições adversas denota muito mais uma condenação a serviços forçados do que uma solução de emprego no campo.

A localização dos agentes produtivos nos territórios é deliberadamente discriminatória. No caso da destinação das terras do planalto santareno para a produção de grãos, a Embrapa e o CPRM fizeram o ZEE que indicou as terras com "aptidão agrícola", inclusive abrindo e generalizando em grande medida o conceito de áreas degradadas, de forma a incorporar a soma de $400 \mathrm{mil}$ ha de áreas mecanizáveis. Assim, o ZEE elaborado pelo governo do estado do Pará protegeu áreas destinadas à exploração mineral, de cujas informações a sociedade em geral é privada.

\section{Regularização parcimoniosa}

Também é estrutural ao sistema de concentração fundiária e ao sistema de gestão pública do território. A parcimônia é um tipo de ação propositalmente lento, calculado. A maioria dos colonos assentados pelo Incra nos projetos oficiais de colonização há 35 anos não tem títulos definitivos. Assim, como quase 100\% dos ribeirinhos descendentes de caboclos e seringueiros não têm como provar a propriedade das áreas que habitam centenariamente, grande parte dos remanescentes de quilombos ainda não tem suas terras asseguradas.

Sem os títulos, todos esses setores baseados numa economia rural em escala familiar estão vulneráveis diante de duas abordagens que se tornam bem características:

a) da grilagem que ocupa os territórios tradicionais com acampamentos armados e monta os meios de exploração e roubo de madeira, como verificado no Riozinho do Anfrísio, nas comunidades ribeirinhas de Prainha e Porto de Moz, no rio Sucunduri (entre Maués e Apuí), no rio Arapiuns e suas cabeceiras em Juruti e Santarém, por exemplo; 
José Heder Benatti / Edna Castro / Thomas Hurtienne / Roberto Araújo de Oliveira Santos / Raimunda Nonata Monteiro da Silva / Roselene de Souza Portela

b) na linguagem jurídica do mercado próprio das associações e cooperativas do Sul que afirmam e "até lamentam" que os ribeirinhos ou colonos não tenham títulos de terra, portanto não sendo donos das propriedades e que tenham que dar lugar aos grupos que apresentem "projetos produtivos" para essas terras "subaproveitadas".

Essa é uma abordagem tão autoritária e invasiva como as dos grileiros armados, por utilizar a arma de um mercado mais moderno para reduzir as populações a uma condição de presença ilegítima (porque ilegal) nos territórios pretendidos por eles.

Nesses casos se trava uma batalha de concepções em que as populações não estão preparadas sequer para justificar sua condição. Nessa situação estão as populações ribeirinhas que ficaram isoladas das organizações sociais que acumularam forças na disputa por territórios, como as que conseguiram regularizações coletivas em forma de Resex's ou PDS's.

A maior fragilidade dessas populações é o isolamento e a ausência de capital crítico, de conhecimento e de informação, o que as torna vulneráveis a ofertas aviltantes de integração a projetos externos, como está ocorrendo com a intensa pressão de aliciamento por grupos de Castelo de Sonhos, Novo Progresso, do Mato Grosso e Rondônia junto aos ribeirinhos do Sul do Amazonas acessado pelas BRs-230 e 319. As associações e cooperativas do Sul também usam desse expediente, segundo seus dirigentes, "indenizando" os antigos posseiros (seringueiros e garimpeiros) que habitam as áreas que lhes foram destinadas pelo Estado.

Em termos de localização geográfica e de relação com as fazendas, mercado urbano e madeireiras, os assentamentos obedecem ao seguinte padrão:

Figura 3: Padrão de Assentamentos em Castelo de Sonhos e Novo Progresso

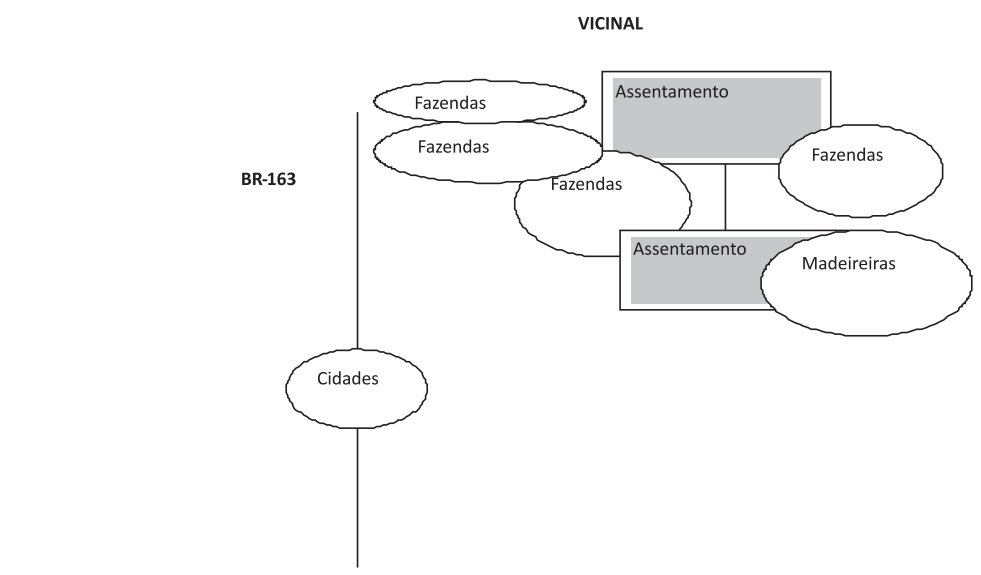

Fonte: CASTRO; MONTEIRO; CASTRO, 2004. 
O esquema do "Quadrado Burro" é explícito na localização e no modelo de assentamento das famílias. Em todos os casos identificados na pesquisa, pelos relatos de seus moradores, esses assentamentos serão integrados à grande propriedade.

A trajetória de ocupação de um assentamento na BR-163 pode ser descrita pela seguinte representação:

Figura 4: Sucessão na posse da terra e assentamentos

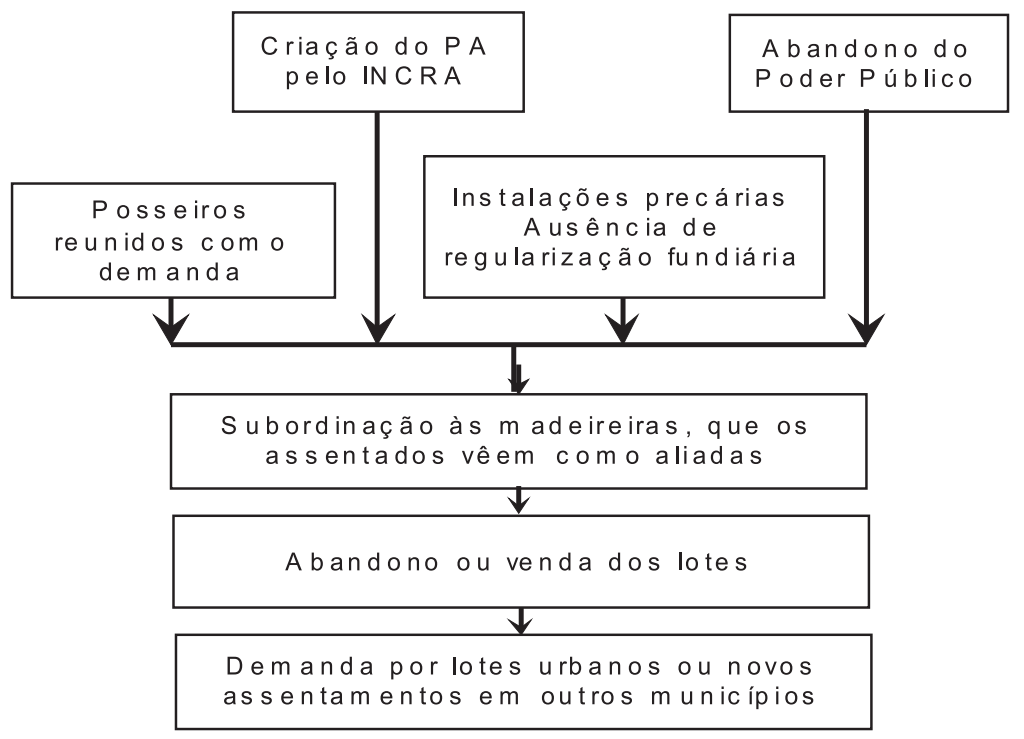

Com esse esquema conclui-se que há uma relação direta entre o modelo de assentamento do Incra e o mercado de terras. Conclui-se também que esse modelo sustenta uma manipulação estrutural da mão-de-obra que transita pelas grandes propriedades da região.

\subsection{QUESTÃO FUNDIÁRIA E CONFLITOS}

A questão fundiária é um fator determinante na situação atual de todos os tipos de pequenos produtores dessa região. Em geral, ninguém tem título de propriedade, mesmo os que chegaram no início do projeto. A ocupação pela pecuária de grande porte, que vem encontrando nessa região sua área de expansão, está resultando numa brutal concentração das terras. A apropriação de vastas áreas pelas empresas madeireiras também restringe as possibilidades de expansão das atividades características da pequena produção. 
Os PA’s do Incra têm sido um mecanismo de assentamento provisório de familias que chegam em busca de terra, geralmente a mais de $30 \mathrm{~km}$ das cidades, em vicinais mantidas precariamente pelas empresas madeireiras. $\mathrm{O}$ abandono dos assentamentos a longas distâncias de qualquer serviço público funciona estruturalmente como mecanismo de "amansamento das terras" para posterior repasse para às empresas pecuaristas e madeireiras.

A instabilidade e a precariedade dos assentamentos determinam uma mobilidade constante das famílias, fazendo um percurso que começa quando chegam nas cidades e conseguem algum trabalho temporário até que são assentados num PA, onde passam cerca de 3 anos, com lavouras de subsistência combinada com a venda da madeira dos lotes. Ao fim desse ciclo, chegam ao limite, pois não serão assistidos com saúde e nem educação. A atividade agrícola que não remunera e o sofrimento do isolamento são razões suficientes para o repasse das terras por preços que variam de $\mathrm{R} \$ 300,00$ a $\mathrm{R} \$ 4.000,00$, dependendo da distância. Em todos os assentamentos, os pretendentes das terras já estão ocupando as bordas. Com a venda, os assentados retornam para as vilas e cidades, onde adquirem lotes urbanos e passam a engrossar a reserva de mão-de-obra errante para as poucas atividades econômicas da região. Outros seguem diferentes rotas de migração. A perspectiva é que se aprofundem a pobreza e os conflitos.

A concentração populacional nas vilas e cidades, sem urbanização, é uma tendência forte, em muitos casos, incentivada pela extensão de energia e telefone e pela oferta de escolas e atendimento de saúde.

A estrutura fundiária baseada em "espinha de peixe" definitivamente é inapropriada e irracional para uma ocupação em que a moradia se situe na extensão das vicinais, pois fica muito cara a manutenção dos serviços. Uma ocupação que combine moradia nos núcleos urbanos e o trabalho em vicinais estruturadas com transporte e a concentração das pequenas propriedades nos primeiros 10 quilômetros, em módulos menores e tecnificados para uma produção intensiva, é a proposta que vem sendo desenvolvida pelos movimentos sociais da área de colonização da Transamazônica. Essa é uma forma de manter a atividade agrícola como ocupação rentável e assegurar conforto e novas oportunidades de trabalho para as populações rurais, diminuindo a penosidade do trabalho.

\subsection{ASPECTOS POLÍTICOS}

A presença do Estado no ordenamento territorial impõe efeitos encadeados exigentes em gestão e governança, mas o Estado (em todas as suas esferas) não está preparado (ou interessado) para realmente impor o que se poderia chamar de 
interesse público na condução dos rumos econômicos da região de influência da BR-163. A este problema estão relacionadas todas as questões que seguem como resultado de análises anteriores aos procedimentos do atual governo e das pesquisas de campo realizados no âmbito do ZEE BR-163. Não se pode perder de vista que os Zoneamentos Econômicos e Ecológicos do Mato Grosso, Amazonas e Pará resultaram muito mais da iniciativa externa de financiadores da área ambiental e do próprio Banco Mundial do que da percepção dos dirigentes de Estado quanto à pertinência do Zoneamento na conjuntura de intensificação da pressão sobre os estoques de recursos naturais. Ao contrário, nos três estados, os governos estavam empenhados em programas de estímulo e na promoção do agronegócio. No caso do Pará, o governo chegou a enviar emissários a municípios do Rio Grande do Sul, Paraná e Santa Catarina a fim de atrair produtores para Novo Progresso e depois Jacareacanga. Prefeitos rumando ao centro-sul em busca da redenção econômica de seus municípios têm no caso de Santarém o mais simbólico.

Deve ser considerado também que entre os grupos sociais mais refratários às medidas de contenção da fronteira estão os agentes econômicos externos pecuaristas, madeireiros e produtores de grãos estabelecidos na região ou não ${ }^{13}$. No caso do trabalho escravo, famílias tradicionais estabelecidas há muito tempo na região, como os Mutran, ainda são acusadas de práticas que marcaram sua trajetória no Sul do Pará ${ }^{14}$.

As empresas madeireiras que mais se mobilizaram contra as medidas de fiscalização e limitação de autorizações de planos de manejo irregulares a partir de 2005 foram as polarizadas por Altamira, com forte participação do setor de Paragominas estabelecido em Pacajá e Anapu; posteriormente, as empresas mobilizadas pelo Sindicato das Indústrias Madeireiras (Simaspa), polarizadas por Itaituba e Novo Progresso. Nos dois casos, os líderes são oriundos de estados do centro-sul do país e falam em nome do "progresso e da geração de empregos na região". São fortemente amparados pelo governo estadual e respaldados por políticos dos seus estados e exercem influência sobre várias prefeituras e câmaras

13 Ver lead da matéria a seguir "O senador João Ribeiro (PFL-TO) foi denunciado nesta quintafeira (17) pelo procurador-geral da República, Cláudio Fonteles, ao Supremo Tribunal Federal por aliciar 38 trabalhadores rurais e sujeitá-los à condição de escravos na fazenda Ouro Verde, de sua propriedade, no município de Piçarra, no Sudeste do Pará” (Agência Repórter Brasil, 17.06.2004). 14 A Lima Araújo Agropecuária Ltda. e suas duas fazendas estão na "lista suja" divulgada pelo governo federal no final do ano passado com 52 propriedades rurais cujas autuações levaram à condenação de seus donos por trabalho escravo. Há na lista apenas cinco nomes que se repetem duas vezes: o da Lima Araújo e o das famílias Andrade, Bannach, Mutran e Quagliato - que possuem fazendas de gado na região Sul do Pará e, historicamente, têm dificultado a erradicação do trabalho escravo na região de expansão agrícola amazônica. (...) Em sua contestação na Justiça, a Lima Araújo critica o Ministério Público do Trabalho devido à desproporção entre a ação anterior de R\$ 30 mil e esta de R\$ 85 milhões” (Agência Carta Maior, 04.02.2004). 
de vereadores. Em 2005, essas empresas conquistaram um espaço significativo junto à opinião pública, apoiados pela imprensa regional.

No processo de mobilização contra as medidas restritivas do governo federal, desencadeadas em $2005^{15}$, ficou demonstrado que o governo do Pará não concordava com a política de restrição e houve mobilização popular conclamada pelas empresas em 2004 na Transamazônica e em 2005 na BR-163.

Interessante observar também que as vozes ambientalistas mais ouvidas nos poderes públicos federais também foram de entidades ou de fora ou com intensas influências externas, com forte capital de formação de opinião pública nacional e internacional, o que as tornou porta-vozes dos movimentos sociais da Amazônia.

\subsection{RELAÇÃO DOS PEQUENOS PRODUTORES COM OUTROS ATORES}

Cada tipo de pequeno produtor se relaciona de uma forma, pois suas diferenciações também determinam graus diferenciados de legitimidade e tolerância diante dos grupos empresarias que comandam a política da região. Os colonos sitiantes são vistos como produtores, os que sabem trabalhar. Em Trairão, é nítida a aversão de dirigentes do Poder Público ao STR por este estar tentando organizar os posseiros para conseguir terra. Em Novo Progresso, há uma verdadeira ideologia que une pequenos proprietários aos médios e grandes para a exclusão dos posseiros e até em termos de organização social. A maior parte dos pequenos produtores está vinculada à associação de produtores ligada à Feapa. Os migrantes dos garimpos assentados nos PA’s são vistos, em geral, como meros trabalhadores, embora todos reconheçam que as dificuldades estruturais desestimulam e justificam vender ou abandonar os lotes.

Pode-se afirmar que os colonos sitiantes são tolerados, embora sejam assediados para vender suas terras, tanto quanto os assentados dos PA's. Os assentados e os posseiros se relacionam com as empresas como reserva de mãode-obra cativa de empresas madeireiras (como no caso do Areias) e como mão-

15 Durante 2005, o Governo Federal desencadeou uma série de campanhas de fiscalização dentro do Plano de Controle do Desmatamento estruturado em 2004 e fortalecido politicamente com a repercussão do assassinato da Irmã Dorothy Stang. Pela primeira vez, houve ação combinada entre Ibama, Incra, Forças Armadas, Polícias Federal e Rodoviária Federal, Ministério Público, entre outros órgãos, para conter os desmatamentos ilegais, tendo como alvo a grilagem de terras e as fraudes na extração e transporte de madeiras. Operações como a Curupira contribuíram para desmontar uma parte do enredamento da ilegalidade e corrupção que, historicamente, minam as relações entre os órgãos ambientais e os sujeitos econômicos na fronteira. Certamente, essas operações surtiram o efeito de choque, mas não de ruptura com os meios mais estruturados que perduram na burocracia e nas relações entre os agentes. 
de-obra barata para a exploração das terras, tanto na oferta da madeira como na destocagem, que facilita a entrada da pecuária. O custo do desmatamento de grandes áreas é alto, sendo desejável aos grandes proprietários que parte desse serviço seja feito pelos pequenos proprietários, às próprias custas.

O conflito também marca a relação com os pecuaristas que pretendem expandir suas áreas nos assentamentos.

A relação com as madeireiras, até onde se pôde perceber, é marcada por uma aliança de sobrevivência. São elas que garantem a estrada e, em alguns casos, o aviamento para a exploração da madeira. São elas que transportam doentes nas emergências. Principalmente, são elas que permitem um mínimo de circulação monetária entre os assentados. As empresas com potencial de industrialização no local são também as depositárias da expectativa de emprego.

\subsection{RELAÇÃO DOS PEQUENOS PRODUTORES COM O ESTADO E O MERCADO}

O Estado agiu deliberadamente como indutor da concentração fundiária por determinados grupos econômicos: da pecuária, por meio da Sudam; da soja, por meio da pesquisa, de incentivos locais e atualmente financiamentos massivos e eufóricos do Banco da Amazônia; da madeira, pela liberação de planos de manejo ilegais em áreas públicas e, ultimamente, na destinação direcionada para grupos econômicos de médios proprietários e profissionais liberais do Sul, que vêem na aquisição de terras públicas na Amazônia uma poupança de longo prazo.

Do lado do Estado, tem-se, até 2002, uma política combinada do nível municipal ao federal favorável ao apossamento latifundista na região, com estreitas alianças entre os setores que buscavam a concentração de terras e os grupos políticos estabelecidos. Essa aliança incluía estruturalmente os esquemas de indicação dos espaços de ocupação de acordo com o poder dos grupos que se instalavam na região.

Em geral, estruturalmente no Brasil e na América Latina, os grupos que se revezam no poder em todas as esferas de governo são oriundos das atividades econômicas com maior peso em seus níveis locais, regionais, estaduais e nacionais. $\mathrm{Na}$ Amazônia se repete essa regularidade, com raras exceções. Relações clientelistas, coronelistas e paternalistas continuam estruturais na política local e estadual, com acentuações mais ou menos relevantes de acordo com o grau de modernização institucional e de controle social.

O número de prefeitos que se elegem e que exercem influência local e estadual é composto, majoritariamente, por pecuaristas, madeireiros e grandes 
comerciantes que, invariavelmente, são orgânicos da economia agrária e integrados ao mercado de terras. Profissionais liberais que alcançam posições de destaque em cargos públicos também são integrados ao sistema agrário dominante. Em São Félix do Xingu, foi possível identificar como a pecuária é orgânica em praticamente todo o capital circulante, sendo objeto de investimentos e poupança de comerciantes e profissionais liberais de todos os portes que utilizam o sistema de criação de meia. São Félix representa um padrão de todos os municípios pecuaristas da fronteira brasileira.

A circulação sistêmica do capital madeireiro durante a vigência dos seus ciclos também explica por que donos de empresas madeireiras ou seus prepostos alcançam o controle das máquinas públicas tão facilmente nos municípios em que se instalam. O capital de subsistência que flui numa grande cadeia de empregos eventuais e sub-remunerados, um fluxo de comércio de equipamentos, combustíveis e mercadorias de aviamento para serviço nas aberturas de mata, o incremento de venda das farmácias pelo acometimento de doenças e outros efeitos micro-encadeados fazem com que a exploração madeireira seja estrutural ao sistema, irrigando a economia por prazos que dependem da capacidade de fornecimento dos estoques.

O prazo de exploração de um estoque geralmente é suficiente para compor alianças econômicas e políticas entre os agentes, empoderando-os para posicionamentos na máquina administrativa local, alianças para eleição de parlamentares orgânicos ao projeto das empresas e para a garantia de governos alinhados com seus interesses. Quanto aos grupos políticos que disputam a máquina estadual é interessante observar como o projeto de poder das elites políticas do Pará, especialmente, teve nos grupos mais agressivos da apropriação de terras públicas e financiamento uma aliança estratégica.

A lógica desse processo é a apropriação de informações públicas (jazidas minerais, estoques florestais, áreas com aptidão agrícola, situação fundiária das áreas) para destinação e uso privado. Nessa lógica, além do acesso facilitado pelos órgãos públicos que detêm as informações e do mercado que se organiza sobre as informações estratégicas, ocorre a transformação das prefeituras, das estruturas públicas de administração em verdadeiras empresas privadas dos setores que dominam a economia e utilizam as máquinas públicas como sua face institucional. Dessa forma, o posicionamento dos grupos que se apropriam dos recursos naturais é funcional ao sistema de limpeza de suas atividades. Por isso, o jogo político nessas regiões não admite contrários.

Destaca-se, também, na participação do Estado o mecanismo que predominou no mercado político de 2000-2002 na região paraense de influência da 
BR-163 e em Anapu, em que a terra se tornou uma moeda de grande capacidade de arregimentação de apoios aos grupos que detinham poder sobre a destinação das terras públicas. Merecem destaque os casos das cooperativas Associação de Produtores de Jacareacanga e Pinhais - RS (Aprojapi), da Associação de Produtores de São Miguel do Oeste - SC (Aproeste) e da Coopercaminhos, formada no Paraná e dirigida a partir de Apuí - AM, que reúne sócios, tudo indica, a maioria de atividades urbanas. Terras da União foram oferecidas a esses grupos que chegaram ao estado organicamente vinculados ao projeto do governo estadual, que lhes prometeu terras regularizadas de 500 ha por família em Novo Progresso inicialmente, depois em Jacareacanga.

As três cooperativas se instalaram precariamente em Jacareacanga, mantendo poucas famílias de sócios nos lotes, apenas para a manutenção das posses. Os seus presidentes continuam morando em suas cidades de origem no Sul e recebem orientação técnica e jurídica diretamente dos seus estados ou de uma base montada em Apuí. Há indícios de que os mesmos grupos já montam seus esquemas de acumulação de terras também no Amazonas, onde há mais terras disponíveis, porém integradas ao mercado, pelas quais teriam que pagar. No Pará, receberiam as terras públicas.

No período atual, percebe-se que o assentamento de clientes legais da reforma agrária é uma determinação prioritária, assim como o georreferenciamento das propriedades. A configurar-se essa determinação, as terras da União em toda essa região estariam com suas destinações privadas determinadas em pouco tempo e cerca de 5 milhões de hectares pertenceriam a agricultores familiares. A política do Incra é também titular as terras em posse de populações tradicionais ou não, nas localidades que já habitam. Isso significa contribuir para os índices da reforma agrária, consagrando posses já consumadas.

A relação com o Incra combina uma expectativa de mediação e solução dos conflitos com a desconfiança em relação aos seus compromissos políticos e a decepção com o fato de que o órgão não funciona quanto aos seus objetivos de ordenamento agrário. Todos os relatos e observações em campo levam a crer que a ação do Incra está dentro de uma estratégia de loteamento de todo o Noroeste do Estado do Pará entre grandes grupos econômicos pecuaristas, mineradores e madeireiros. Uma leitura histórica, dando a relevância devida aos personagens que estiveram por trás das decisões sobre o destino das terras dessa região, nos últimos vinte anos, poderia vir a concluir que há uma política articulada de privatização das terras e de manipulação da pequena produção como força de trabalho para essa economia.

Segundo o Iterpa, a política deve priorizar o repasse das terras estaduais para médios e grandes proprietários, amparada pelo Macrozoneamento Econômico 
José Heder Benatti / Edna Castro / Thomas Hurtienne / Roberto Araújo de Oliveira Santos / Raimunda Nonata Monteiro da Silva / Roselene de Souza Portela

e Ecológico já instituído, em lotes permitidos constitucionalmente de até 2.500 ha. A maior parte das terras da Calha Norte pertencem ao governo do Pará e o Macrozoneamento já prevê essas áreas para consolidação agropecuária. O critério ecológico é secundário nessa determinação.

O processo de ordenamento territorial representa um choque de modernidade com o protagonismo do Estado, criando as condições de regulação do uso da terra para uma economia de mercado com algum nível de governança na região. É interessante observar que os conflitos de interesses em torno da destinação das áreas têm um fórum de resolução entre o governo federal e estadual. As interlocuções locais por meio de consultas públicas serviram para identificar alinhamentos políticos de projetos: i) conservacionista - governo federal e organizações sociais locais; ii) desenvolvimentista - governo do estado e representações empresariais e prefeituras. As duas vertentes podem ser traduzidas também como: i) distributivistas (conservacionistas) e ii) concentracionistas (desenvolvimentistas), de modo que os dois projetos estão polarizados na disputa de espaço territorial, econômico e político em toda essa região. E estão conflagrados.

Essas observações têm o objetivo de chamar a atenção para a necessidade de reforçar as medidas de legitimação social dos instrumentos de ordenamento territorial, a efetivação de medidas de controle social e a instauração de fato do Estado de Direito, ampliando os meios de governança para a implementação das medidas.

As questões destacadas a seguir são de ordem estrutural e devem ser abordadas no ZEE e nas demais medidas subseqüentes, com vistas à solidificação de instrumentos públicos de gestão econômica, social e ambiental.

Com o poder público, o conflito aumenta quanto maior for a exclusão social. É o caso das prefeituras, vistas em todos os municípios como aliadas dos pecuaristas e das madeireiras, associadas a esquemas de desvios de recursos dos projetos de assentamentos. Os Prefeitos são representantes políticos desses grupos sociais e almejam se constituir em uma nova elite influente no Pará.

A relação das áreas de abrangência da BR-163 com o mercado é determinada, principalmente, pelo mercado de terras para a expansão de atividades produtivas baseadas na oferta de matérias-primas encontradas em abundância nos estoques de recursos naturais da Amazônia. A rodovia estava dentro de uma estratégia do Estado e dos segmentos produtivos que influenciam os governos, como acesso a uma fronteira de expansão de atividades produtivas que vêm se transferindo de várias regiões do país, no sentido Sul-Norte.

A BR-163 teve um ritmo acelerado de ocupação no final dos anos 1990 e início de 2000. Efetivamente, houve uma corrida de novos atores que chegaram 
e o aumento da demanda de madeira, de carne e seus derivados, de soja e outros grãos, em nível nacional e internacional, pressionando novas terras para expansão do mercado. Mas, principalmente, as terras antes utilizadas para essas atividades apresentam sinais de esgotamento ecológico, demandando elevados custos de produção. No caso da madeira, muitas empresas se deslocam porque as florestas a que a BR-163 dá acesso são generosas, com espécies de elevado valor de mercado, a fiscalização é dificultada pelas distâncias e pela ausência do Poder Público e o controle político dos municípios está sendo feito por uma elite que tem a mesma visão de progresso.

A relação com o mercado é mais intensa e significativa em relação a duas mercadorias: a madeira e a terra. No caso dos assentados, a madeira é uma mercadoria com rápido esgotamento. Isso depende muito do estoque presente nas áreas que eles dominam. A terra é a mercadoria mais procurada atualmente na região, principalmente por empresas madeireiras, famílias estabelecidas no CentroSul especulando sobre a valorização dessas áreas e por agricultores interessados na produção de grãos em grande escala.

Os colonos sitiantes mantêm uma relação com o mercado de gado, com vendas esporádicas a título de poupança. Alguns vendem para manter um limite de rebanho compatível com o tamanho dos pastos. Na média de produtividade da região, sem tecnologias, em áreas de 15 a 20 ha, o rebanho não pode passar de 100 cabeças. Esse é o limite para quem tem até 200 ha de terras mantendo as reservas legais.

\section{EXPERIÊNCIA DE COLONIZAÇÃO DIRIGIDA NA ÁREA DE ABRANGÊNCIA DA BR-163}

Os projetos de colonização planejada implantados no espaço amazônico na área de abrangência da BR-163 foram formulados a partir da implantação do Programa de Integração Nacional, em 1970, e estavam associados a problemas sociais decorrentes da seca que atingia a região Nordeste. A situação começava a tornar-se demasiadamente crítica, em função do grande número de retirantes que invadia propriedades rurais e centros urbanos, provocando arrombamentos e saques. Neste contexto, o presidente Emílio Garrastazu Médici, após visitar a região nos dias 04 a 06 de junho de 1970, declarando-a sob o estado de calamidade pública, baixava, no dia 16 desse mesmo mês, o Decreto-Lei n ${ }^{\circ}$. 1.106, criando o PIN.

Esse Decreto ressaltava que o programa tinha como objetivo financiar um plano de infra-estrutura nas regiões que compreendiam áreas de atuação da Sudam 
José Heder Benatti / Edna Castro / Thomas Hurtienne / Roberto Araújo de Oliveira Santos / Raimunda Nonata Monteiro da Silva / Roselene de Souza Portela

e da Sudene e promover a mais rápida integração dessas duas regiões à economia nacional. A primeira etapa do programa seria constituída pela construção imediata das rodovias Transamazônica e Santarém-Cuiabá, sendo que as margens dessas rodovias $(10 \mathrm{~km})$ serviriam para a colonização. Com tais medidas, o governo federal tinha por objetivo:

$1^{\circ}$ - promover a ocupação efetiva, a organização agrícola e a exploração mineral de amplas áreas da Amazônia, a fim de incorporá-la ao contexto econômico-social brasileiro;

$2^{\circ}$ - orientar e fomentar a migração do nordestino para a Amazônia.

A colonização iniciada no ano de 1971 foi centralizada, basicamente, na rodovia Transamazônica, e o Estado do Pará adotou, como modelo de concepção, os chamados PIC's, cujo objetivo era o assentamento de agricultores de escassos recursos financeiros e os trabalhadores rurais sem terra.

Ao Incra coube a jurisdição de $100 \mathrm{~km}$ de cada margem das rodovias federais, que deveria administrar dentro do quadro de referência dos Projetos Integrados de Colonização (PICs), sediados em Altamira e Itaituba, na Transamazônica, e em Monte Alegre, na Perimetral Norte. Esses projetos, que faziam parte do PIN, deveriam fornecer aos colonos assentados: salário de subsistência por seis meses - enquanto aguardavam a colheita de sua produção anual; serviços de extensão agrícola e crédito supervisionado; infra-estrutura essencial; serviços de comercialização e outros benefícios.

Segundo o plano de colonização para a Amazônia, a faixa de $100 \mathrm{~km}$ de cada lado da rodovia Transamazônica seria assim ocupada: os primeiros $10 \mathrm{~km}$ seriam ocupados pelos pequenos agricultores em lotes de 100 ha para atividades agrícolas. Os $90 \mathrm{~km}$ restantes seriam ocupados por lotes de 500 a 3.000 ha, vendidos em leilões nacionais a pessoas jurídicas interessadas na exploração da pecuária.

Os PICs deveriam colocar à disposição dessa clientela toda uma infraestrutura de apoio, propiciada, por um lado, pela implantação de uma infra-estrutura hierarquizada de centros urbanos administrativos e residenciais e, por outro lado, pelo oferecimento de um conjunto de incentivos necessário ao desenvolvimento das atividades agrícolas nas áreas rurais.

Em território paraense foram implantados três PICs no trecho da Transamazônica, compreendido entre os municípios de Marabá e Itaituba: PIC-Marabá, PIC-Altamira e PIC-Itaituba.

A estrutura hierarquizada de centros urbanos administrativos e residenciais, implantados pelo Incra, intencionava concretizar o conceito de urbanismo rural composto de três níveis hierárquicos: as agrovilas, as agrópolis e as rurópolis. 
Os colonos não deveriam residir nos lotes rurais de 100 ha onde desenvolviam suas atividades produtivas, e sim nas agrovilas, unidades básicas do sistema urbano, que eram formadas, em média, por um conjunto de 50 lotes urbanos com igual número de casas. Nas agrovilas havia: 01 posto médico, 01 escola de $1^{\circ}$. grau, pequeno comércio, 01 igreja, 01 centro comunitário, 01 campo de futebol e, em alguns casos, 01 armazém para estocagem da produção agrícola.

As agrópolis, com uma população entre 1.500 e 4.000 habitantes, seriam pequenos centros urbanos com função agroindustrial, cultural e administrativa. Exerciam sua influência sobre um conjunto de 8 a 12 agrovilas, num raio de abrangência de 10 a 20 km e continham serviços como: administração rural, extensão agrícola, enfermaria, comércio de varejo, oficinas de reparos, bancos, correios, telefones, escolas de $1^{\circ}$. e $2^{\circ}$. graus, etc.

A rurópolis, projetada para abrigar até 20.000 habitantes, oferecia maior amplitude de serviços, incluindo aeroporto, hospitais, hotéis, cinemas, etc. Cada rurópolis assumiria a função de um pequeno pólo de desenvolvimento e centro principal de uma grande comunidade rural, constituída por agrovilas e agrópolis distribuídas num raio de 70 a $140 \mathrm{~km}$.

Assim, além do lote rural para o trabalho, do lote urbano com uma casa para fixar residência e dos serviços prestados pelos núcleos urbanos implantados, o parceleiro ainda teria um salário mínimo por seis meses, crédito sob baixos juros e garantia da compra da produção por bons preços.

Foi sob esse modelo de ocupação espacial concebido pelo PIN e detalhado pelos PICs, objetivando tornar realidade a colonização dirigida nas margens das rodovias de integração nacional, que surgiu no Estado do Pará, na confluência da Transamazônica com a Santarém-Cuiabá, integrando o PIC-Itaituba, a única rurópolis implantada pelo Programa, denominada Rurópolis Presidente Médici, e que, posteriormente, tornou-se núcleo gerador do município de Rurópolis.

Nesses termos, a evolução econômica e o processo histórico de ocupação do recém-criado município de Rurópolis, confundem-se, em grande parte, com a própria história de implantação e desenvolvimento do PIC-Itaituba ${ }^{16}$.

A área de ação do projeto compreende terras dos municípios de Aveiro, Santarém, Itaituba e Rurópolis e teve como a primeira sede administrativa a comunidade de Miritituba, pertencente ao município de Itaituba. Posteriormente, a administração foi transferida para a Rurópolis Presidente Médici, que, atendendo às especificações do sistema de urbanização rural hierarquizado, incorporou du-

16 Esse PIC foi criado pelo Decreto nº 67.557, de 12 de novembro de 1970, e teve sua implantação iniciada no ano de 1972. Possuía inicialmente 1.026.679 ha e, atualmente, abrange 6.341 .750 ha. $\mathrm{Na}$ área do polígono desapropriado já foram ocupados 3.546.500 ha e, fora do polígono, 215.100 ha, perfazendo um total de 3.761 .600 ha (INCRA, 1986). 
rante sua construção, concluída em 1974, a infra-estrutura básica necessária para transformar-se em pólo de desenvolvimento regional.

Em 1972, com a chegada das primeiras famílias que procediam das regiões Sul, Nordeste e da própria região Norte, iniciava-se o processo de ocupação da área de abrangência do PIC-Itaituba. Essas famílias chegavam com todas as despesas pagas pelo governo federal, incluindo passagens aéreas, ranchos, salários, ferramentas, etc. Eram instaladas ao longo da Transamazônica em unidades residenciais construídas pelo Incra. As casas eram de madeira serrada e tinham em média 52,80 $\mathrm{m}^{2}$ de área construída. Ao todo, até 1974, foram construídas 581 casas. A partir de então, o programa habitacional do Incra ficou restrito à promoção de campanhas junto aos colonos não beneficiados, para que eles próprios construíssem ou melhorassem suas habitações, pois normalmente residiam em cabanas.

Logo após os primeiros assentamentos, os colonos desenvolviam uma agricultura tipicamente de subsistência: arroz, feijão, milho e mandioca. Depois, de acordo com suas aptidões e orientação do Incra, iam diversificando suas atividades, passando a cultivar algumas culturas perenes, como cacau, pimenta-do-reino, banana, guaraná, abacaxi etc.

A partir de 1974, ano da conclusão da Transamazônica e da Rurópolis Presidente Médici, o governo federal, sob o pretexto de que a colonização dirigida, concebida pelo PIN, baseada em minifúndios e voltada para o pequeno produtor migrante, estava confinada ao fracasso, como resultado da ação predatória do colono e da baixa produtividade de sua produção agrícola, resolveu redirecionar a política de ocupação da Amazônia implantando, a partir de então, o Programa de Pólos Agropecuários e Agrominerais da Amazônia (Polamazônia).

Entretanto, apesar desse novo redirecionamento da política de ocupação do território amazônico, não cessou o processo de migração de pequenos agricultores para a região, considerando que a Transamazônica, uma vez concluída, possibilitava maiores liberdades de acesso, fazendo com que uma colonização espontânea, sobre a qual o Incra não conseguia exercer seu controle, detonasse, paralelamente, a colonização dirigida. Atualmente, a realidade do PIC-Itaituba é totalmente contrastante com aquela do início de sua implantação. Das cercas de 11.000 famílias existentes no projeto, poucas são as que reúnem alguma condição para superar as dificuldades que assolam a região da Transamazônica. 


\section{DESAFIOS PARA O DESENVOLVIMENTO ECONÔMICO DA REGIÃO}

As condições para o desenvolvimento do mercado formado em torno de uma economia extensiva em recursos naturais são incomparavelmente superiores ao que se pode chamar de protocondições para uma proto-economia em bases sustentáveis na Amazônia.

É preciso maior atenção e profundidade nas reflexões que atestam a ausência de um mercado nas suas clássicas acepções na fronteira. Na verdade, são vários os mercados presentes. E o que se observa na Amazônia hoje é que o efeito "toque de Midas", que transforma em "ouro" - mercadoria - tudo que toca, se dá pela ação do agente externo. Em todas os segmentos econômicos. Em todos os recursos potencialmente transformáveis em moeda.

Na economia agrária de commodities, o referencial monetário é fixado pelo produto que movimenta a economia e nisso não se diferem das economias de subsistência: os produtores de grãos de São José dos Pinhais ou Rodeio Bonito (RS) precisam de 300 a 500 sacas de soja para comprar 1 hectare de terra, o que justifica sua vinda para a Amazônia - essa é a moeda corrente para eles; os preços das commodities nas regiões produtoras de cacau são o referencial de moeda; assim como nos garimpos os custos e os preços são calculados com base no mercado do ouro. Quanto maior o valor de troca das mercadorias, maiores são os custos com que os agentes econômicos se dispõem a arcar.

Os indicadores econômicos da região de influência da BR-163 demonstram maior resiliência econômica dos municípios com base produtiva mais diversificada. Indicadores sociais demonstram também que o virtuosismo econômico das regiões que concentram a maior produção do agronegócio não tem o mesmo rebatimento em empregabilidade, regularidade trabalhista, serviços públicos de saneamento e abastecimento de lixo. O encadeamento entre economia primária e terciária também não é correspondente.

Os municípios que se destacam por uma economia equilibrada entre produção madeireira, pecuária, plantios permanentes e culturas anuais são os da Transamazônica, mais precisamente entre Rurópolis e Pacajá, com as ressalvas das distorções ocorridas em Anapu e Pacajá, ocasionadas pelas frentes madeireiras recentes. A pauta da produção agropecuária compreende: cacau, pimenta, pecuária, madeira, banana, mandioca, urucum, frutas e pequenos animais para o auto-abastecimento. Esse padrão, grosso modo, também se reproduz na região de colonização do Apuí (AM). 
No Mato Grosso, a maioria dos municípios apresenta baixo grau de diversificação, com forte orientação para commodities de exportação. Aqueles que diversificam também apresentam mais equilíbrio de seus indicadores econômicos e sociais. São casos de municípios que estão na transição da madeira, pecuária e produção de grãos em que os indicadores retratam uma simultaneidade desses segmentos. Mas a tendência é fechar os ciclos de esgotamento da madeira e pecuária extensiva e se concentrar na produção de grãos, convivendo com uma pecuária moderna em menor escala.

Essas questões são pontuadas com vistas a chamar a atenção para a tese amplamente difundida de que uma condição básica da eficiência econômica estaria na diversificação da base produtiva - questão central para a economia rural da Amazônia, considerando sua condição primordial de diversidade.

\section{CONSIDERAÇÕES}

Por existir uma densidade demográfica e uma integração ao mercado relativamente altas, não se pode falar mais somente de uma agricultura de subsistência miserável nas margens das fronteiras agrárias ou, como alternativa, de uma agricultura comercial de médio porte com fortes insumos externos. O que se desenvolveu nas zonas de colonização mais antigas na terra firme do Pará (Zona Bragantina, depois a Guajarina), mas também na Transamazônica, são sistemas de produção diversificados que conseguiram ultrapassar alguns dos limites inerentes a uma agricultura migratória ou itinerante: certa estabilização das agriculturas familiares num nível socioeconômico que - apesar de não satisfatório - pelo menos consegue limitar migrações expressivas para as cidades e novas fronteiras agrárias. Essa estabilização relativa se deu também dentro de sistemas de uso da terra que utilizam somente poucos insumos externos, a não ser o uso abundante da energia solar para o sistema de pousio. Os limites inerentes dessa agricultura de pousio (seu encurtamento enfraquece a fertilidade já limitada do solo) foram superados pela integração sucessiva de culturas perenes ou do gado, o que implica novos limites, mas, também, oportunidades para um sistema sustentável.

Apesar de todas as incertezas quanto à sustentabilidade a médio e a longo prazos desses sistemas de produção familiar na região, pode-se levantar a hipótese de que essas formas de uso da terra foram ou podem ser bem mais sustentáveis ecológica, econômica e socialmente do que foi percebido pelos cientistas naturais e pelas agências políticas na Amazônia, no Brasil e no âmbito internacional. Além disso, os sistemas de produção familiar oferecem também possibilidades de integrar cultivos (agro)florestais e pecuária, facilitando a tração animal (como 
substituto ao uso de tratores). Isso implica também que um redirecionamento das políticas agrárias em favor da agricultura familiar e do desenvolvimento rural sustentável pode ter uma gama de possibilidades bem mais abrangente do que foi convencionalmente pensado.

\section{REFEREANCIAS}

ARAÚJO, Roberto. Terra do Meio: Poder, Violência e Desenvolvimento. Debate Idéias. Coordenação Ima Vieira. Belém: MPEG, 2003. (no prelo).

BENATTI, José Heder; ARAÚJO, Roberto; PENNA, Socorro. A Grilagem de Terras Públicas na Amazônia Brasileira. Brasília: MMA/AMA/PPG-7 IPAM, 2006.

BRASIL. Legislação do Meio Ambiente: atos internacionais e normas federais. Brasília: Senado Federal, Subsecretaria de Edições Técnicas, 1996.

BRASIL. Congresso. Comissão Parlamentar de Inquérito destinada a investigar a Ocupação de terras públicas na região amazônica. Brasília: Câmara dos Deputados - Coordenação de Publicações, 2002.

CASA CIVILDA PRESIDÊNCIADA REPÚBLICA. Plano de Desenvolvimento Sustentável para a Área de Influência da BR-163: Oficina de Consulta à Sociedade Local. Brasília, 2004.

Plano de Desenvolvimento Regional Sustentável para a Área de Influência da Rodovia BR-163. Brasília, 2005.

CASTRO, Edna. Estado e Políticas Públicas na Amazônia: Gestão Pública e Desenvolvimento. In: COELHO, Maria C. N. \& MATHIS, Armin (org). Políticas Públicas e desenvolvimento Local na Amazônia: Uma agenda de debate. Belém: UFPA/NAEA, 2005.

CASTRO, Edna; MONTEIRO, R e CASTRO, Carlos. P. Atores e Relações Sociais em Novas Fronteiras na Amazônia. Relatório de Pesquisa. Brasília: Banco Mundial, 2002.

Dinâmica de Atores, Uso da Terra e Desmatamento na Rodovia Cuiabá-Santarém. Belém: Paper do NAEA nº 179, 2004.

Atores Sociais na Fronteira mais Avançada do Pará: São Félix do Xingu e a Terra do Meio. Belém: Paper do NAEA, nº 180, 2004. 
MARTINEZ, G. A Evolução Espacial da População Brasileira. In: AFFONSO, R., SILVA, P. (Orgs.). Federalismo no Brasil. Desigualdades regionais e desenvolvimento. São Paulo: FUNDAP/UNESP, 1994.

MONTEIRO, Raimunda. Os Desafios a serem Enfrentados para a Efetividade do Ordenamento Territorial, 2006.

OCTAVIO, Rodrigo. Do domínio da União e dos Estados: segundo a Constituição Federal. $2^{a}$ ed. São Paulo: Livraria Acadêmica: Saraiva, 1924.

PARÁ, Governo do. Relatório da Comissão de Estudos das Áreas de Jurisdição Federal no Território do Estado do Pará. Belém, Fevereiro de 1996. 